\title{
A consensus map for Ug99 stem rust resistance loci in wheat
}

\author{
Long-Xi Yu • Hugues Barbier • Matthew N. Rouse • \\ Sukhwinder Singh $\cdot$ Ravi P. Singh $\cdot$ Sridhar Bhavani · \\ Julio Huerta-Espino $\cdot$ Mark E. Sorrells
}

Received: 18 April 2014 / Accepted: 5 May 2014 / Published online: 6 June 2014

(C) The Author(s) 2014. This article is published with open access at Springerlink.com

\begin{abstract}
Key message This consensus map of stem rust genes, QTLs, and molecular markers will facilitate the identification of new resistance genes and provide a resource of information for development of new markers for breeding wheat varieties resistant to Ug99.

Abstract The global effort to identify new sources of resistance to wheat stem rust, caused by Puccinia graminis f. sp. tritici race group Ug99 has resulted in numerous studies reporting both qualitative genes and quantitative trait loci. The purpose of our study was to assemble all available information on loci associated with stem rust resistance from 21 recent studies on Triticum aestivum L. (bread wheat) and Triticum turgidum subsp. durum desf. (durum wheat). The software
\end{abstract}

L.-X. Yu and H. Barbier contributed equally to this research.

Communicated by Beat Keller.

Electronic supplementary material The online version of this article (doi:10.1007/s00122-014-2326-7) contains supplementary material, which is available to authorized users.

L.-X. Yu · H. Barbier · M. E. Sorrells $(\bowtie)$

Department of Plant Breeding and Genetics, Cornell University, Ithaca, NY 14853, USA

e-mail: mes12@cornell.edu

Present Address:

L.-X. Yu

United States Department of Agriculture, Agricultural Research Service, Vegetable and Forage Crops Research Unit, 24106 N.

Bunn Road, Prosser, WA 99350-9687, USA

M. N. Rouse

United States Department of Agriculture, Agricultural Research Service, Cereal Disease Laboratory and Department of Plant Pathology, University of Minnesota, St. Paul, Minneapolis, MN 55108, USA
LPmerge was used to construct a stem rust resistance loci consensus wheat map with 1,433 markers incorporating Single Nucleotide Polymorphism, Diversity Arrays Technology, Genotyping-by-Sequencing as well as Simple Sequence Repeat marker information. Most of the markers associated with stem rust resistance have been identified in more than one population. Several loci identified in these populations map to the same regions with known $\mathrm{Sr}$ genes including $\mathrm{Sr} 2, \mathrm{SrND} 643$, Sr25 and Sr57 (Lr34/Yr18/Pm38), while other significant markers were located in chromosome regions where no $\mathrm{Sr}$ genes have been previously reported. This consensus map provides a comprehensive source of information on 141 stem rust resistance loci conferring resistance to stem rust $\mathrm{Ug} 99$ as well as linked markers for use in marker-assisted selection.

\section{Introduction}

Wheat stem rust caused by the pathogen Puccinia graminis Pers. f. sp. tritici Eriks. and E. Henn., is one of the most

\author{
S. Singh $\cdot$ R. P. Singh $\cdot$ S. Bhavani \\ International Maize and Wheat Improvement Center (CIMMYT), \\ Apdo. Postal 6-641, 06600 Texcoco, Mexico \\ J. Huerta-Espino \\ Campo Experimental Valle de México INIFAP, Apdo. Postal 10, \\ 56230 Chapingo, Edo de México, Mexico
}


destructive wheat diseases. It can cause up to $90 \%$ yield loss in wheat production but has been effectively under control due to the successful deployment of resistance genes in wheat cultivars since the 1950s (McIntosh et al. 1995). However, the outbreak of a new stem rust race in Uganda named Ug99 (race TTKSK; Pretorius et al. 2000) spread throughout much of Africa, the Middle East and Iran and poses an imminent threat to wheat production worldwide (Singh et al. 2006; Sharma et al. 2013).

To improve the efficiency of wheat breeding for durable resistance to stem rust, it is essential to understand the genetic basis. To-date, 58 stem rust resistance $(\mathrm{Sr})$ genes have been numerically designated in wheat as part of the International Wheat Genetics Symposium Gene Catalog (McIntosh et al. 1995, 2011). Several alleles conferring unique race specificities have been identified for many of these genes resulting in a total of 65 numerically designated resistance genes and alleles. Of these genes and alleles, phenotypic data have been published indicating that at least 27 are effective or partially effective to the Ug99 race group: $S r 2$ ( $Y r 30$ ), $S r 13, S r 21, S r 22, S r 24, S r 25, S r 26$, Sr27, Sr28, Sr32, Sr33, Sr35, Sr36, Sr37, Sr39, Sr40, Sr42, Sr44, Sr45, Sr46, Sr47, Sr51, Sr52, Sr53, Sr55 (Lr67/Yr46/ Pm46), Sr57 (Lr34/Yr18/Pm38), Sr58 (Lr46/Yr29/Pm39) (Faris et al. 2008; Ghazvini et al. 2012; Kolmer et al. 2011; Jin and Singh 2006; Jin et al. 2007; Liu et al. 2011a, b; McIntosh et al. 2012; Rouse et al. 2011; Rouse and Jin 2011; Singh et al. 2013b, c). Several additional resistance genes have been characterized as resistant to Ug99; however, their relationship to numerically designated genes has not been determined: SrAes7t, SrCad, SrND643, SrTA10171, SrTA10187, SrTA1662, SrTmp, SrWeb, SrlRS Amigo (Hiebert et al. 2010, 2011; Jin and Singh 2006; Jin et al. 2007; Klindworth et al. 2012; Olson et al. 2013). It is possible that such genes with temporary designations are redundant with, or are alleles of, numerically designated genes. Several of the numerically designated $\mathrm{Sr}$ genes are qualitative and race specific (Jin et al. 2007; Singh et al. 2011). Qualitative genes are phenotyped as present or absent, often at the seedling stage by observing the characteristic low or high infection types displayed by them as described by Jin et al. (2007). One strategy for achieving durable resistance is to pyramid multiple qualitative resistance genes into each wheat variety. A major risk associated with the utilization of qualitative resistance genes is the ability of pathogens to defeat such genes when they are deployed alone in wheat cultivars as has been demonstrated by the original Ug99 defeating $\operatorname{Sr} 24, \operatorname{Sr} 36$, and resistance in cultivar 'Matlabas' resulting in "Boom and Bust" cycles (Jin et al. 2008, 2009; Pretorius et al. 2012).

Utilization of quantitative resistance, often based on multiple minor genes that slow down pathogen infection and colonization in adult plants, referred to as 'Adult Plant
Resistance' (APR) (Gustafson and Shaner 1982), is another approach for achieving durable resistance. Adult plant resistance to stem rust in wheat is a complex trait conferred by quantitative trait loci (QTL). This type of resistance can be more durable than single gene resistance due to race non-specificity of the resistance genes involved. A total of five numerically designated wheat stem rust resistance genes confer quantitative APR: $S r 2$, Sr55 ( $\operatorname{rr67/Yr46/~}$ Pm46), Sr56, Sr57 (Lr34/Yr18/Pm38), and Sr58 (Lr46/ Yr29/Pm39). In addition, several recent studies have identified numerous QTL associated with wheat stem rust resistance in diverse germplasm (Bansal et al. 2008; Bhavani et al. 2011; Crossa et al. 2007; Kaur et al. 2009; Njau et al. 2013; Rouse et al. 2014; Singh et al. 2013a, b, c; Yu et al. 2011, 2012).

The global effort to identify new sources of resistance to $\mathrm{Ug} 99$ has led to the identification of putative new qualitative and quantitative resistance loci reported in numerous studies in the past few years in different populations. As resistance loci are reported, it is important to determine their potential redundancy in order to prioritize those that can be deployed in a breeding program. The purpose of this study was to compile available information on Ug99 resistance loci and their map locations in a single consensus map to facilitate future mapping studies. The map locations from various sources were analyzed along with our recent association mapping projects involving 608 spring and winter wheat breeding lines from CIMMYT and the International Winter Wheat Improvement Program (Yu et al. 2011, 2012). The consensus map contains Diversity Arrays Technology (DArT), Single Nucleotide Polymorphism (SNP), Genotyping-by-Sequencing (GBS) and Simple Sequence Repeat (SSR) markers to facilitate cross-referencing markers and Ug99 resistance loci with other maps.

\section{Materials and methods}

Literature review and synthesis of stem rust resistance loci

Stem rust resistance loci data were collected from 21 recent studies, for a total of 24 biparental mapping populations, 3 association panels, $2 \mathrm{BC}_{2}$ populations, and two from resistance gene cloning (Bansal et al. 2008; Bhavani et al. 2011; Crossa et al. 2007; Ghazvini et al. 2012; Haile et al. 2012; Hiebert et al. 2010, 2011; Kaur et al. 2009; Letta et al. 2013; Olson et al. 2013; Njau et al. 2013; Periyannan et al. 2013; Rouse et al. 2012, 2014; Saintenac et al. 2013; Singh et al. 2013a, b, c; CIMMYT unpublished, Yu et al. 2011, 2012) (Table 1). The details of the reports, including the chromosome positions of stem rust resistance loci, their LOD ( $\log ($ Odds) $)$ scores and $p$ values, parents used to develop the population as well as stem rust pathotypes for 
disease reaction are presented in Table 1. Three of the studies did not determine stem rust resistance loci by screening with Ug99 (Bansal et al. 2008; Crossa et al. 2007; Kaur et al. 2009). Though included these loci in our study, their effectiveness against Ug99 is unknown and are presented because of their relevance to Ug99 studies.

\section{Construction of a consensus map}

A consensus genetic map was constructed using the Wheat Interpolated Maps v4 (Diversity Arrays Technology Pty. Ltd., personal communication) as a reference map.

(http://www.triticarte.com.au/). DArT, SNP, GBS and SSR markers from the Wheat KASPar SNP database (http://www.cerealsdb.uk.net/CerealsDB/SNPS/), the 2004 Wheat SSR Consensus Map (Somers et al. 2004), and the Thatcher/McNeal map (Sherman et al. 2013) with concatenated DArT and SSR markers were integrated to the reference map using the ad hoc $\mathrm{R}$ package "LPmerge" (Endelman and Plomion 2011) and BioMercator V3.0 (http://moulon.Inra.fr). LPmerge is an optimized "synthetic" (Wenzl et al. 2006) or "composite" (Hudson et al. 2012) approach to built a map across multiple populations. As opposed to minimizing an objective function based on the observed recombination frequencies between markers (JoinMap; Van Ooijen 2006) or (MultiPoint; Ronin et al. 2012), this $R$ package based its algorithm directly on the component linkage maps instead of the recombination frequencies. Other software uses the same approach, but LPmerge implements an additional algorithm for resolving ordinal conflicts found when the marker order was not consistent between the different linkage maps. Resistance loci or QTL associated with stem rust resistance identified from 21 studies and one personal communication (Table 1) were projected onto the consensus map based on the position of the markers linked to the loci when the precision of the constructed map allowed it (Fig. 2). A star following the chromosome number on Table 1 tags the QTL not present on Fig. 2.

\section{Results}

Overview of loci for stem rust resistance

The constructed consensus map contains a total of 1,433 markers distributed among the 21 chromosomes. Fourteen percent of these markers are SNP, $16.7 \%$ are GBS, $39.4 \%$ are DArT and $29.9 \%$ are SSR. With a global average distance of $2.7 \mathrm{cM}$ between markers, the maximum average distance between markers is observed on chromosome 5D (16 markers) with $7.6 \mathrm{cM}$ and the minimum average distance between markers is observed on chromosome $3 \mathrm{~B}$
(158 markers) with $1.9 \mathrm{cM}$. An expected negative correlation is observed between the marker number per chromosome and average distance in centimorgan between markers $(r=0.719)$. The average chromosome size was $150 \mathrm{cM}$ with a maximum of $203.3 \mathrm{cM}$ for chromosome $7 \mathrm{~A}$ and a minimum of $83.4 \mathrm{cM}$. Resistance gene and QTL maps and gene cloning information from 21 studies and one personal communication (Table 1) involving 24 mapping populations, three association panels, and two $\mathrm{BC}_{2}$ populations were concatenated to construct a map for stem rust resistance loci (Fig. 1). The map consists of 141 stem rust resistance loci distributed across the genome, many of which were redundant loci detected in at least two studies. A total of 37, 86 and 18 resistance loci were located in the A, B, and D genomes, respectively (Fig. 1). Several hotspots of resistance loci were observed across the genome. Nineteen were located on chromosome arm 3BS, while 6BS, 5BL and 2BL had nine, nine, and seven QTL, respectively. Among these hotspots, qualitative genes for stem rust resistance have been mapped on $3 \mathrm{BS}, 2 \mathrm{BL}$ and $5 \mathrm{BL}$, while no qualitative genes have been characterized on 6BS. Clusters of QTLs were located distally on 5BS, 6BS and 7AS in regions where no previously reported qualitative or quantitative genes are located.

Chromosome group 1 had 15 QTL and the cloned gene, Sr33, across the three homoeologous chromosomes. Six QTL were found on 1A (two on the short arm, three on the long arm and one is still in an undetermined arm location), five using bi-parental crosses (Thatcher/McNeal: Rouse et al. 2014; PBW343/Kingbird: Bhavani et al. 2011; PBW343/Kenya Swara; Kristal/Sebatel: Haile et al. 2012 and PBW343/Kenya Kudu: CIMMYT unpublished) and one using association mapping (LD-SRRSN (winter): $\mathrm{Yu}$ et al. 2012). Five of these QTL are represented in Fig. 2. One qualitative Ug99 resistance gene was mapped on 1A: SrlRS. ${ }^{\text {Amigo }}$ (Schlegel and Kynast 1987; Jin and Singh 2006; McIntosh et al. 2012). Seven QTL were found on 1B (three on the short arm, three on the long arm and one is still in an undetermined arm location). Four were mapped using bi-parental crosses (PBW343/Crossbill, PBW343/Kenya Nyangumi: CIMMYT unpublished; Avocet/Pavon76: Njau et al. 2013; Bhavani et al. 2011) and three using association mapping (ESWYT: Crossa et al. 2007; LD-SRRSN (spring): Yu et al. 2011 and the AM durum panel: Letta et al. 2013). Four of these QTL are represented in Fig. 2. Sr31 (marker XwPt-8949) is on a 1BL.1RS rye translocation and is homologous with at least three of the QTL found in that region. Sr14, from tetraploid wheat origins (Heerman and Stoa 1956), was also reported on 1B, close to the centromere (McIntosh et al. 1995). The response of $\mathrm{Sr} 14$ to $\mathrm{Ug} 99$ has been reported as inconclusive by Jin et al. (2007) and is not displayed in Fig. 2. Two QTL were mapped on chromosome 1D (one on the short arm and one 


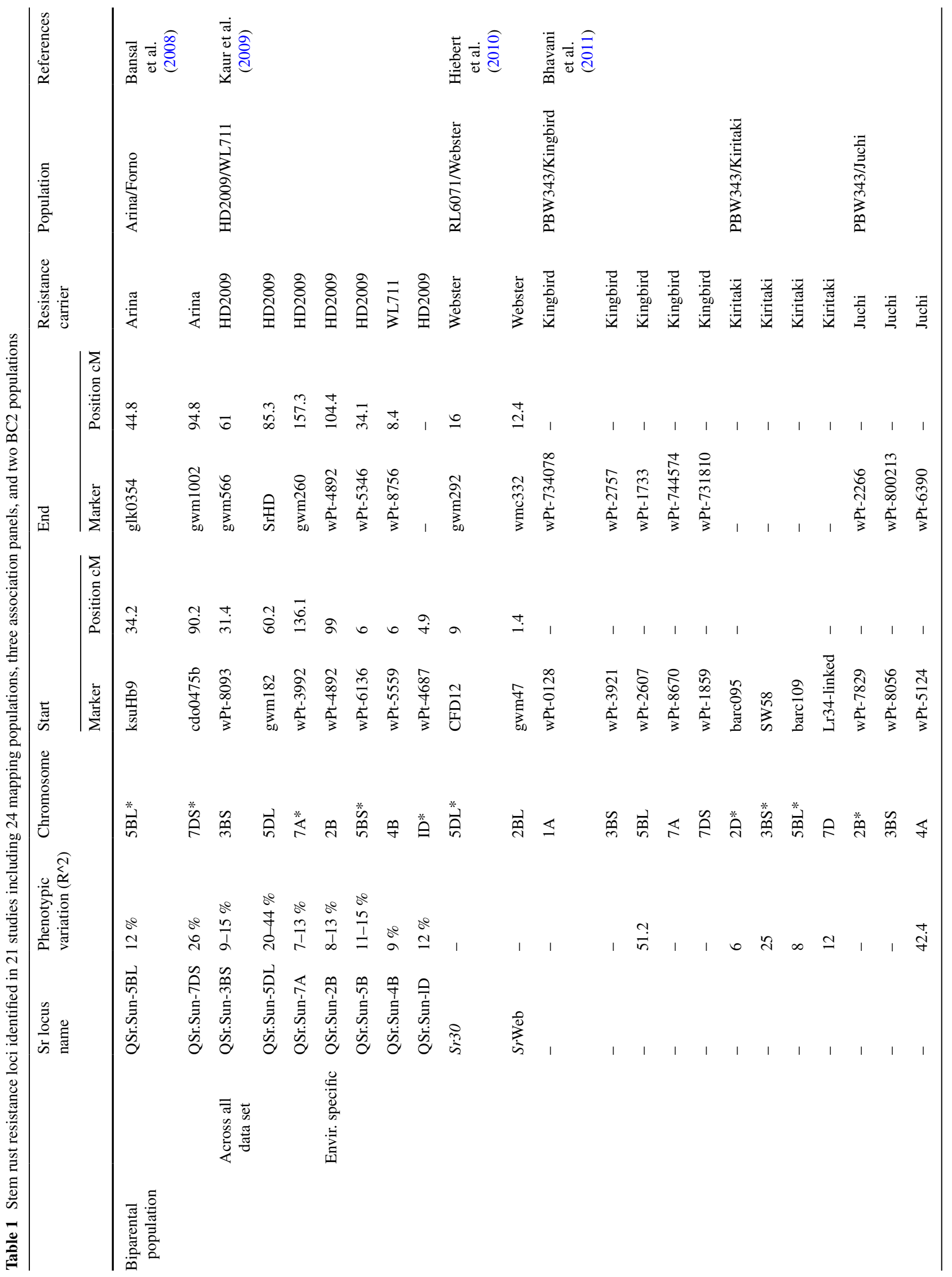




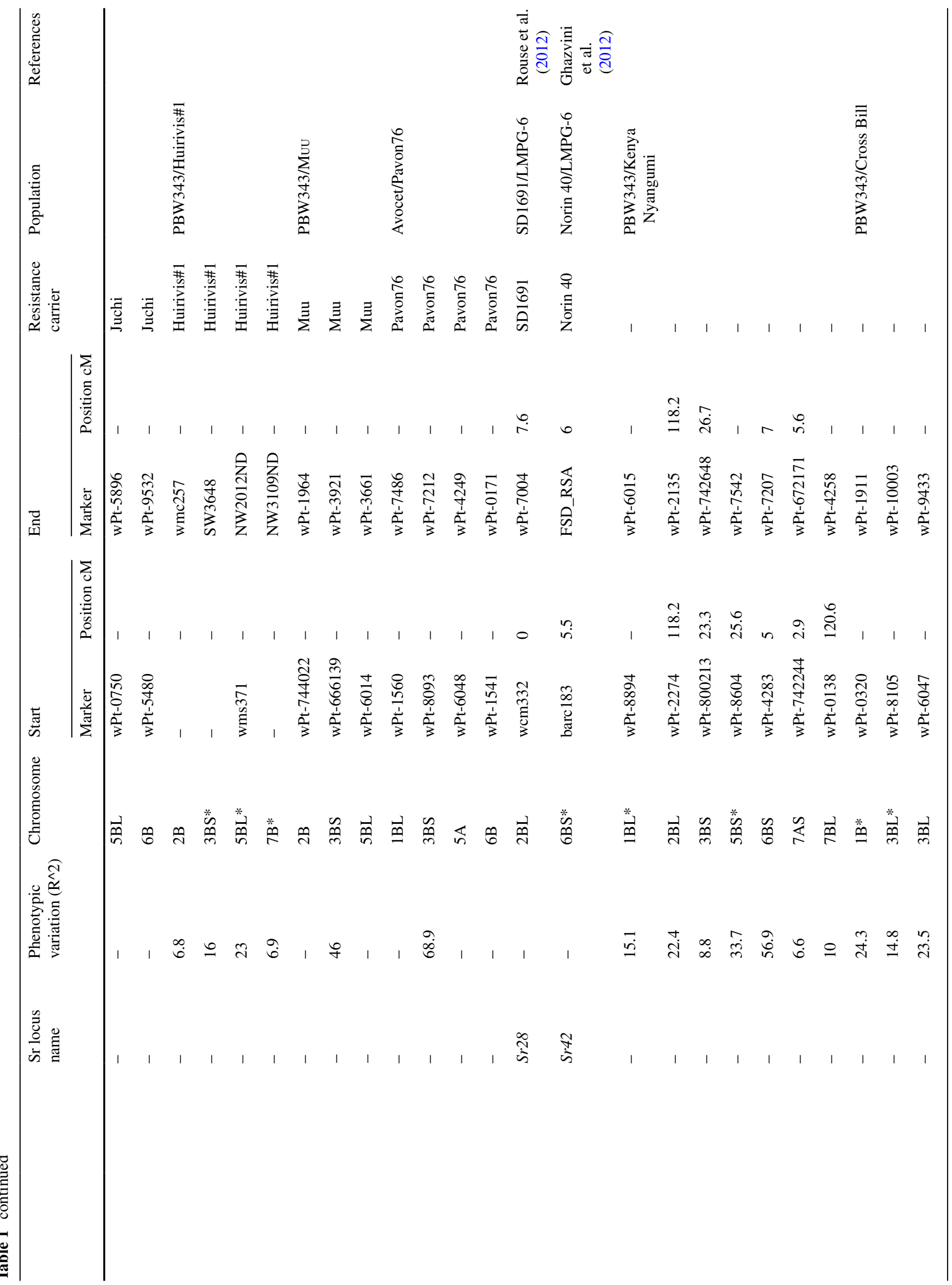




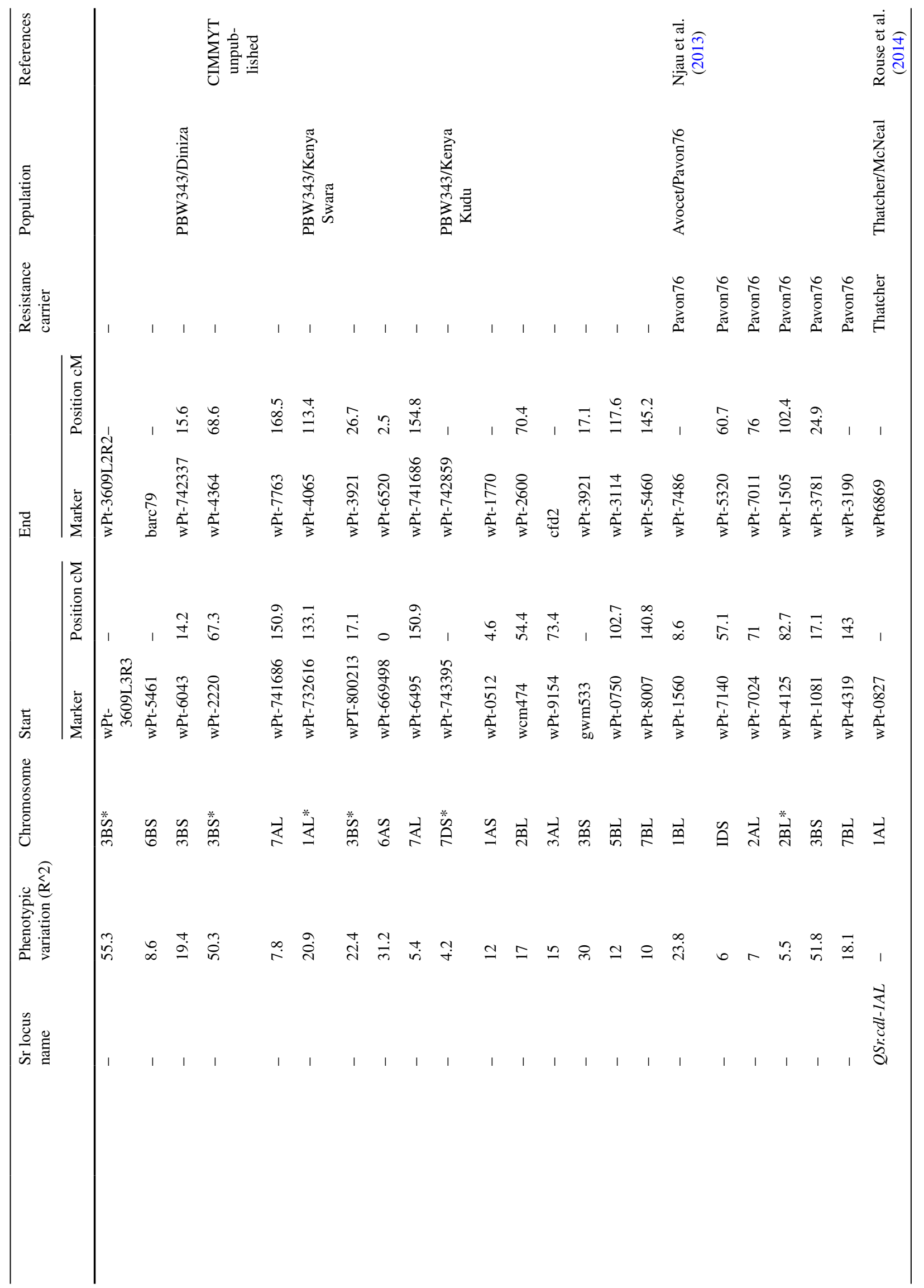




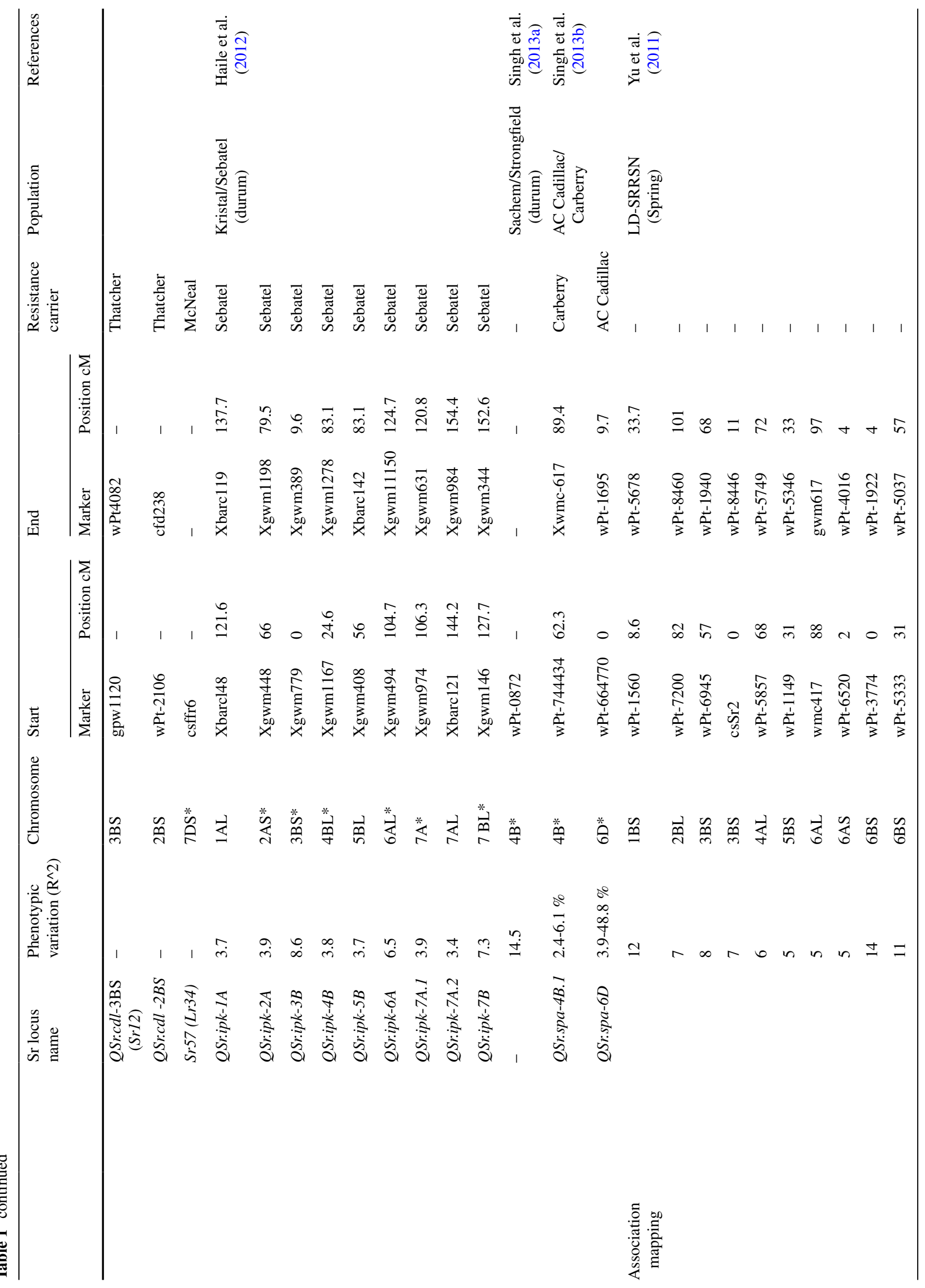




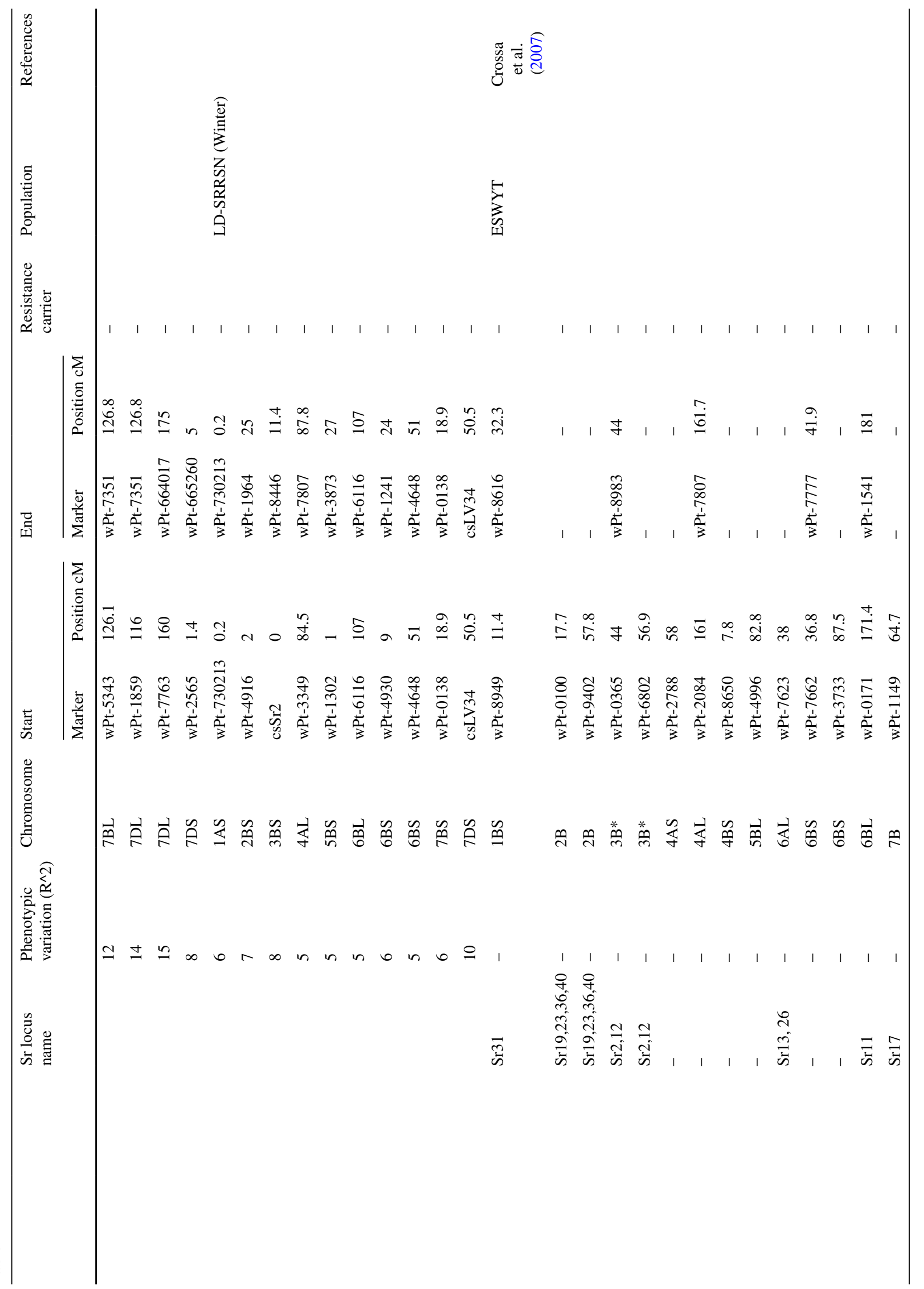




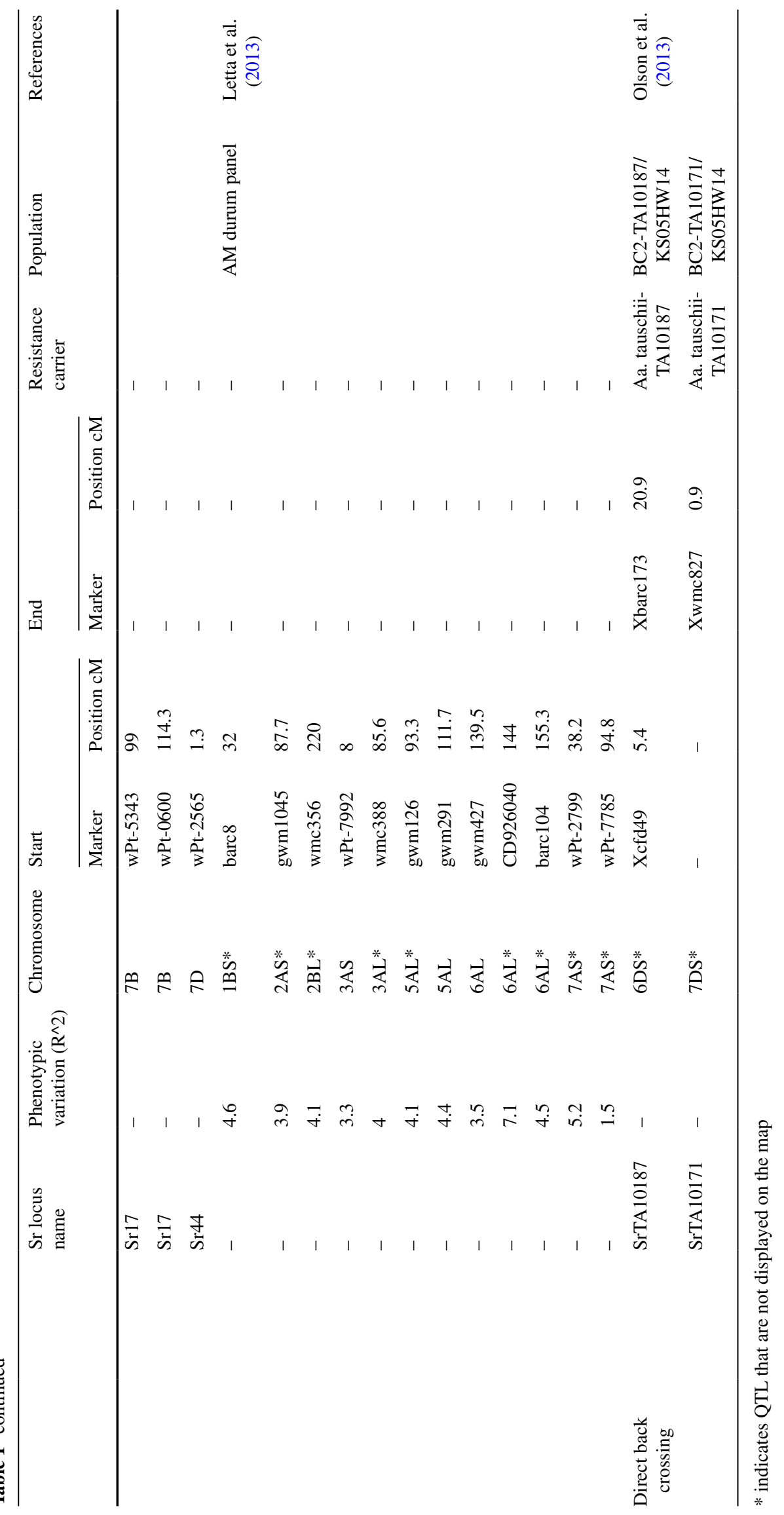



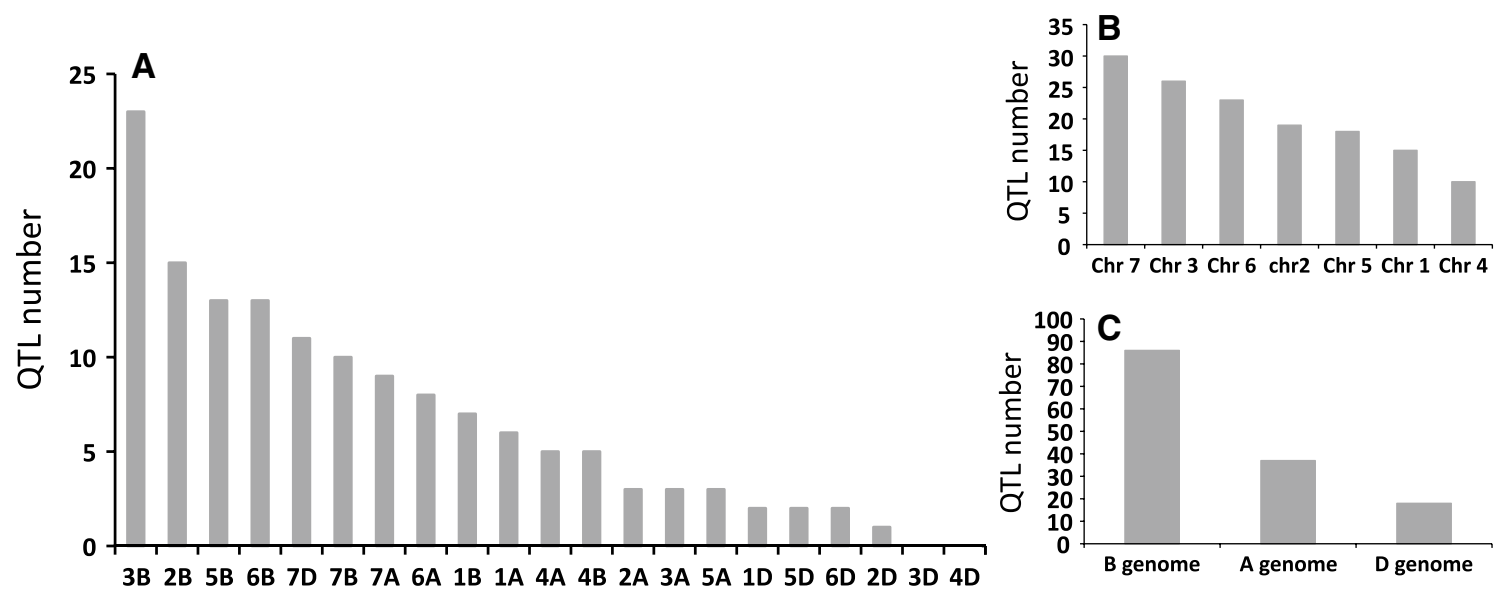

Chromosome arms

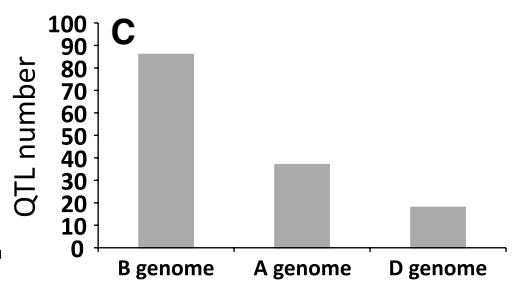

Fig. 1 a Distribution of QTL associated with stem rust resistance by chromosome arm based on 21 studies. b Distribution of QTL associated with stem rust resistance by chromosome based on 21 studies. $\mathbf{c}$

in an undetermined arm location) using bi-parental crosses (HD2009/WL711: Kaur et al. 2009; Avocet/Pavon76: Njau et al. 2013). One of these QTL is represented in Fig. 2. The QTL linked to XwPt-7140 on 1DS coincides with at least one of the four known $\mathrm{Sr}$ genes located in that region (SrTA1662, Sr33, Sr45, Sr50: Rouse et al. 2011; Sambasivam et al. 2008; Anugrahwati et al. 2008).

Chromosome group 2 had 19 QTL across the three homoeologous chromosomes. The short arm of chromosome 2A has two QTL where the centromeric stem rust resistance gene $\operatorname{Sr} 21$ (The 1973) is located and the long arm had one QTL. One of these is represented in Fig. 2. Two $S r$ genes have been described on chromosome 2A, Sr21 (The 1973), derived from Triticum monococcum L., as well as $\mathrm{Sr} 32$ (McIntosh et al. 1995). It has to be noted that stem rust gene $\mathrm{Sr} 32$ has also been mapped on chromosome 2B (McIntosh et al. 2011) as well as 2D (Mago et al. 2013). These three locations are displayed in Fig. 2, and $\mathrm{Sr} 32$ is displayed distally to each chromosome 2 arm in Fig. 2. Chromosome 2B is the location of 15 QTL (two on the short arm, seven on the long arm and the arm location of six loci are unknown), 10 mapped in bi-parental crosses (Avocet/Pavon76: Njau et al. 2013; PBW343/Kenya Nyagumi and PBW343/Kenya Kudu: CIMMYT unpublished; PBW343/Juchi, PBW343/Huirivis\#1, PBW343/Muu: Bhavani et al. 2011; HD2009/WL711: Kaur et al. 2009; RL6071/Webster: Hiebert et al. 2010; SD1691/LMPG-6: Rouse et al. 2012; Thatcher/McNeal: Rouse et al. 2014) and 5 detected using association mapping (ESWYT: Crossa et al. 2007; LD-SRRSN (spring); AM durum panel: Letta et al. 2013 and LD-SRRSN (winter): Yu et al. 2011). Twelve of these loci are shown in Fig. 2. There are 11 designated $\mathrm{Sr}$ genes on 2B (seven of them are shown in Fig. 2)
Distribution of QTL associated with stem rust resistance by genome based on 21 studies

in addition to Ug99-effective $\mathrm{SrWeb}$ (Hiebert et al. 2010). At least two QTL were identified on 2BS where seven $\mathrm{Sr}$ genes have been reported. Among them, Sr39 (Niu et al. 2011), $S r 40$ (Wu et al. 2008), and $\operatorname{Sr} 36$ (Rouse et al. 2012) are effective against the original Ug99 race TTKSK and became ineffective to the variant TTTSK (Jin et al. 2009). Resistance genes $\mathrm{SrWeb}, \mathrm{Sr} 28$, and $\mathrm{Sr} 47$ have been reported on chromosome arm 2BL (Faris et al. 2008; Hiebert et al. 2011; Rouse et al. 2012). Chromosome 2D also had a single QTL in a bi-parental cross (PBW343/Kiritati: Bhavani et al. 2011; location not shown). Chromosome 2DS carries two qualitative $S r$ loci ( $S r 32$ and $S r 46$; Mago et al. 2013; E. Lagudah, personal communication, 2010) at the position of the QTL near marker Xbarc 90 .

On chromosome group 3, 26 QTL were reported as well as a cloned gene across the three homoeologous chromosomes. A single QTL was mapped on 3AS using association mapping (AM durum panel: Letta et al. 2013) and two QTL were mapped on $3 \mathrm{AL}$, one using a bi-parental cross (PBW343/Kenya Kudu: CIMMYT unpublished) and one by association mapping (AM durum panel: Letta et al. 2013). Two of these QTL are shown in Fig. 2. Chromosome $3 \mathrm{~A}$ carries two $\mathrm{Sr}$ genes, one cloned by Saintenac et al. (2013), Sr35 on the long arm and the other one, Sr27, is located on the short arm (Acosta 1963). The other 23 QTL were on 3B ( 2 are on the long arm, 19 on the short arm and the locations of 2 are unknown). Eighteen were mapped using bi-parental crosses (Thatcher/McNeal: Rouse et al. 2014; PBW343/Crossbill, PBW343/Kenya Nyangumi, PBW343/Diniza, PBW343/Kenya Swara, PBW343/Kenya Kudu and PBW343/Pavon76: CIMMYT unpublished; HD2009/WL711: Kaur et al. 2009; PBW343/Kingbird, PBW343/Kiritaki, PBW343/Juchi, PBW343/Huirivis\#1, 


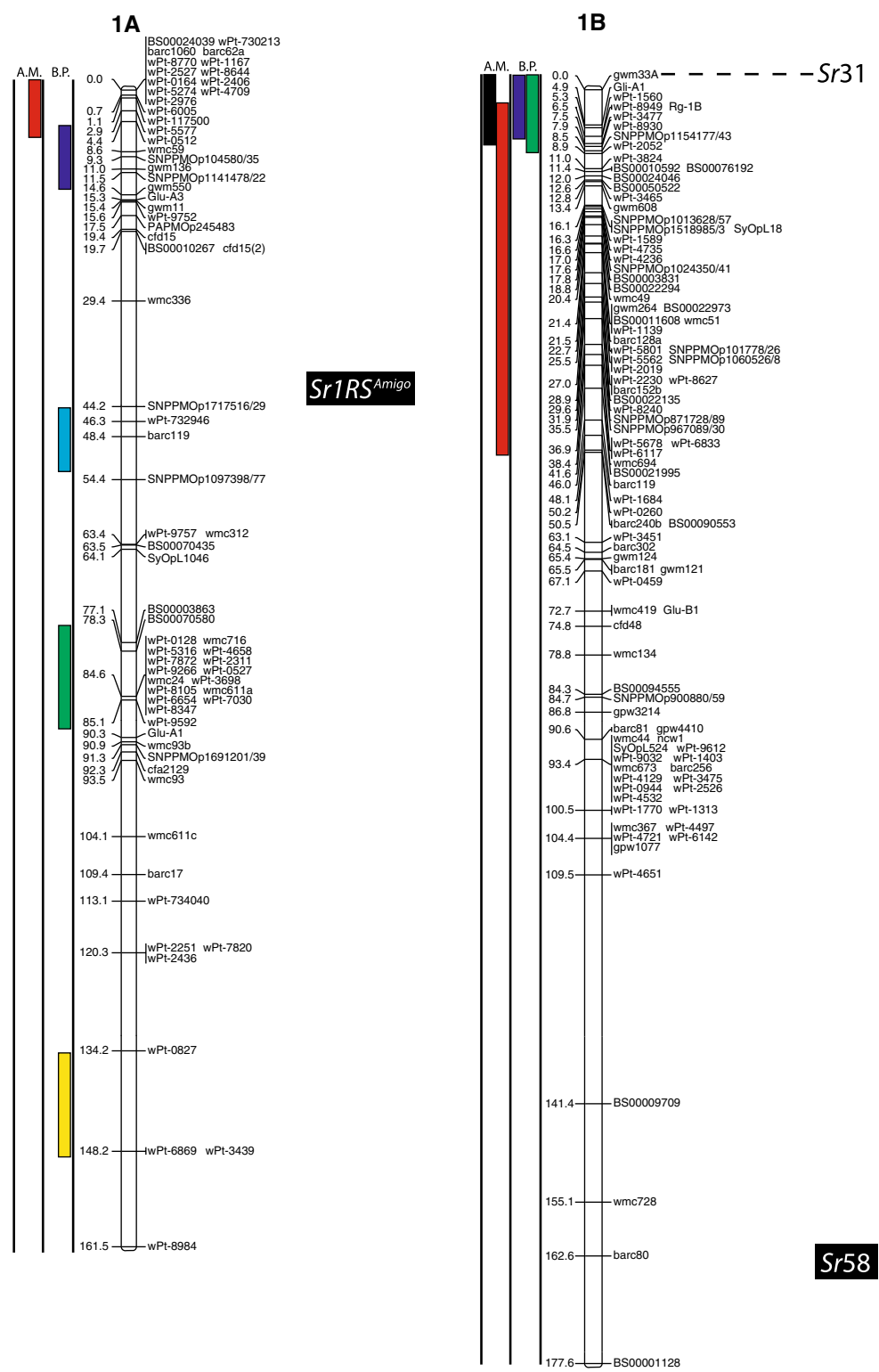

1D

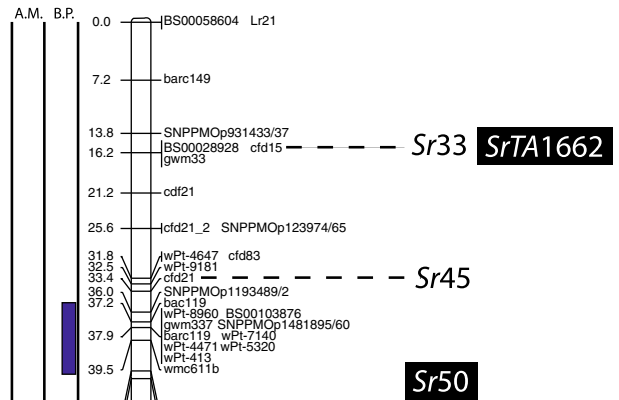

44:3

47.3 $\mathrm{BS} 00078897$

$\left.\begin{array}{l}50.6 \\ 51.4 \\ 58.7\end{array}\right]\left[\begin{array}{lll}B S 00034563 \\ \text { BSS00010435 }\end{array}\right.$

\begin{tabular}{lll}
58.7 & & WPt-3743 \\
61.7 & & \\
\hline & &
\end{tabular}

67.6- - SyOpL1660

$70.2-$ wPt-6059

70.2

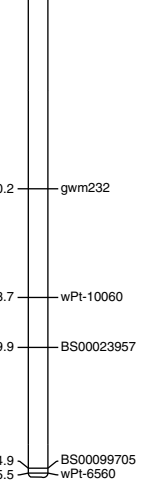

Fig. 2 A consensus map of stem rust resistance loci in wheat. The map was constructed using the Wheat Interpolated Maps v4 (Diversity Arrays Technology Pty. Ltd., personal communication) as a reference map. DArT (prefix "wPt"), SNP (prefix "BS" or "SNP") and SSR markers linked to stem rust resistance loci were integrated as described in the "Materials and methods". The bars with different

PBW343/Muu and Avocet/Pavon76: Bhavani et al. 2011 and Kristal/Sebatel: Haile et al. 2012). Five were mapped by association analysis (ESWYT: Crossa et al. 2011; LDSSRN (spring): Yu et al. 2011). Ten of the mapped loci are shown in Fig. 2. Eleven of the QTL on chromosome 3BS are coincident with the slow rusting gene, $S r 2$, that contributes to APR (Singh et al. 2006). QTL near the centromere of chromosome $3 \mathrm{~B}$ appear to be linked to the seedling resistance gene $\operatorname{Sr} 12$. Though $\operatorname{Sr} 12$ was not characterized as effective as Ug99 (Jin et al. 2007), recent data suggest colors or patterns on the left side of chromosome regions distinguish mapping populations used in each study as shown in Table 1. Major genes that overlapped with QTLs were added to the right side of chromosomes based on the positions of the linked markers. A.M. association mapping, B.P. bi-parental population

that it interacts with other resistance loci to confer APR to Ug99 (Rouse et al. 2014).

Ten QTL were located on group 4 chromosomes. One QTL was located on 4AS, three were on 4AL and one was at an unknown location. Among them, one was identified using a bi-parental cross (PBW343/Juchi: Bhavani et al. 2011) and four using association mapping (LDSRRSN (winter) and LD-SRRSN (spring): Yu et al. 2011; ESWYT: Crossa et al. 2007). Chromosome 4A carries one $\mathrm{Sr}$ gene temporarily designated as SrND643 (CIMMYT 

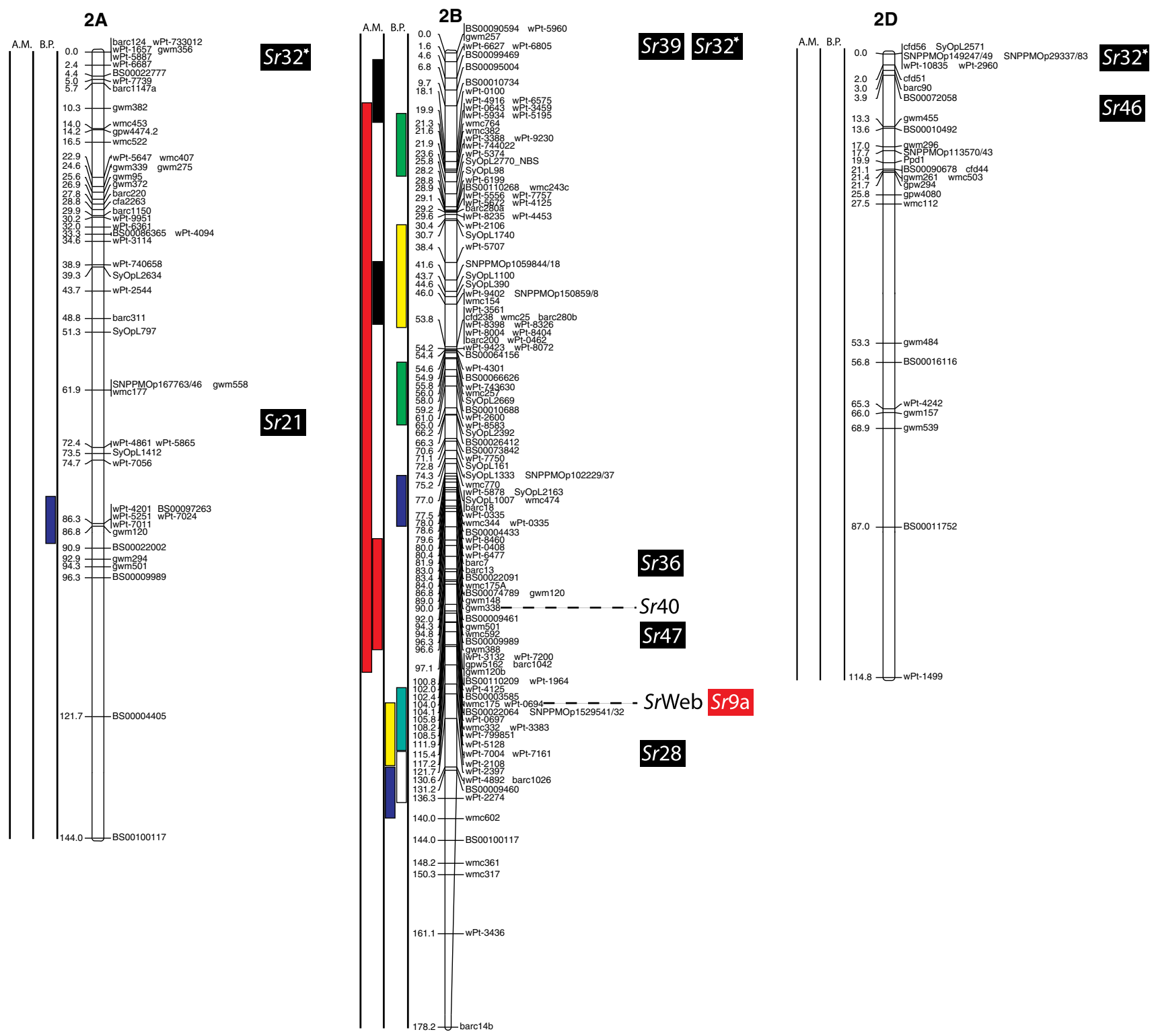

Fig. 2 continued

unpublished), overlapping with QTL from several studies. Though Ug99 effective resistance gene $\mathrm{Sr} 37$ has been introgressed into chromosome $4 \mathrm{~B}$, this translocation has not been used in a breeding program (McIntosh et al. 1995). We did not identify any QTL coincident with the previously described APR gene $\mathrm{Sr} 55$ ( $\mathrm{Lr67/Yr46/Pm46)}$ (McIntosh et al. 2012) on chromosome arm 4DL.

Group 5 had 18 QTL, 3 of which were on chromosome $5 \mathrm{~A}$. One of them was identified using a bi-parental cross (Avocet/Pavon76: Njau et al. 2013), and two by association mapping (AM durum panel: Letta et al. 2013). Two of these loci are shown in Fig. 2. Thirteen QTL were found on chromosome 5B, ten using bi-parental crosses (Arina/Forno: Bansal et al. 2008; PBW343/Kingbird, PBW343/Kiritaki,
PBW343/Juchi, PBW343/Huirivis\#1 and PBW343/Muu: Bhavani et al. 2011; PBW343/Kenya Kudu and PBW343/ Kenya Nyangumi: CIMMYT unpublished; Kristal/Sebatel: Haile et al. 2012) and three using association mapping (ESWT: Crossa et al. 2007; LD-SSRN (Spring) and LDSSRN (winter): Yu et al. 2011). Eight of the 5B QTL are shown in Fig. 2. Kaur et al. (2009) detected a distal 5BS QTL in three of the four environments tested using a bi-parental population. This finding was confirmed by Yu et al. (2011) in the detection of two QTL distally located on chromosome 5BS by association mapping in spring and winter CIMMYT germplasm between markers XwPt1149/XwPt 5346 and XwPt1302/XwPt3873, respectively. Both QTL were minor but overlapped with the QTL detected by Kaur et al. (2009) 

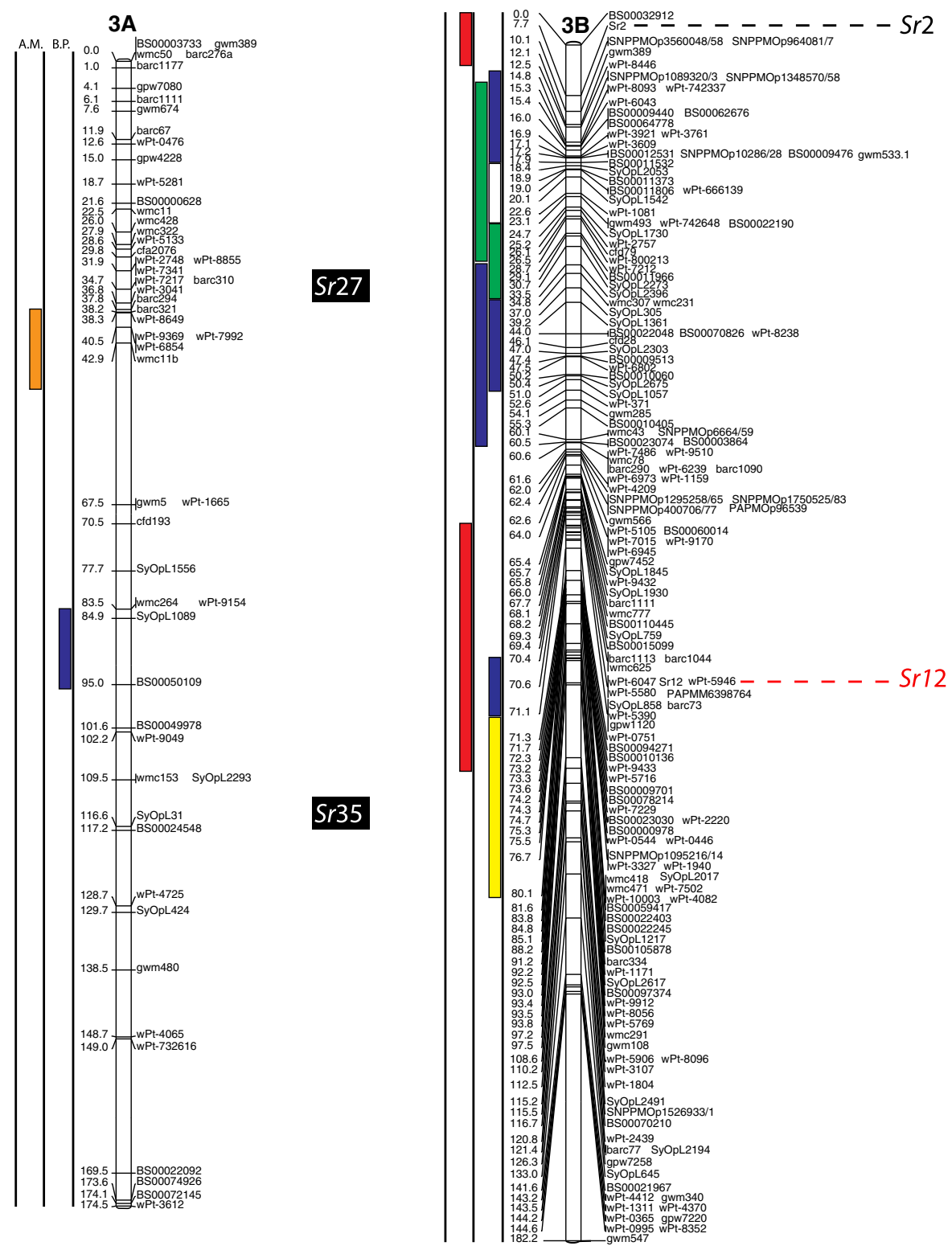

3D

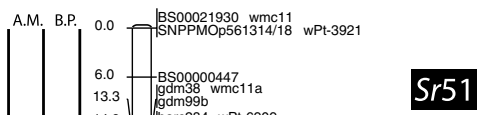

$S r 51$

Fig. 2 continued

(marker $w$ Pt5346). The QTL on 5BL from the Arina/Forno population was recently designated as $\mathrm{Sr} 56$ (McIntosh et al. 2012) and confers APR. No other stem rust resistance genes have been designated on chromosome 5B. Ug99 resistance gene $\mathrm{Sr} 53$ was recently introgressed from Aegilops geniculata to chromosome arm 5DL where two Ug99 QTL were identified using bi-parental crosses (HD2009/WL711: Kaur et al. 2009; RL6071/Webster: Hiebert et al. 2010).

Group 6 had 23 QTL across the three homoeologous chromosomes. On chromosome 6A two QTL were on the short arm and six on the long arm. Two were mapped using a biparental cross (PBW343/Kenya Swara: CIMMYT unpublished; Kristal/Sebatel: Haile et al. 2012) and six using association mapping (ESWT: Crossa et al. 2007; LD-SRRSN (spring): Yu et al. 2011; AM durum panel: Letta et al. 2013). Five of the 6A loci are represented in Fig. 2. Three designated $\mathrm{Sr}$ genes are located on 6A, including three Ug99 resistance genes located on chromosome arm 6AL (Sr26, Sr13, and Sr52; Hart et al. 1993; McIntosh 1972; Qi et al. 2011). Sr52 is not currently used in breeding programs. On 6B there were 13 QTL (nine on the short arm, two on the long arm and two have an unknown arm location), 5 were mapped in biparental crosses (PBW343/Juchi, Avocet/Pavon76: Bhavani et al. 2011; PBW343/Crossbill, PBW343/Kenya Nyangumi: CIMMYT unpublished; Norin40/LMPG-6: Ghazvini et al. 2012) and 8 by association analysis (LD-SRRSN (spring) and LD-SRRSN (winter): Yu et al. 2011; ESWYT: Crossa et al. 2007). Twelve of these QTL are represented in Fig. 2. No 
4A

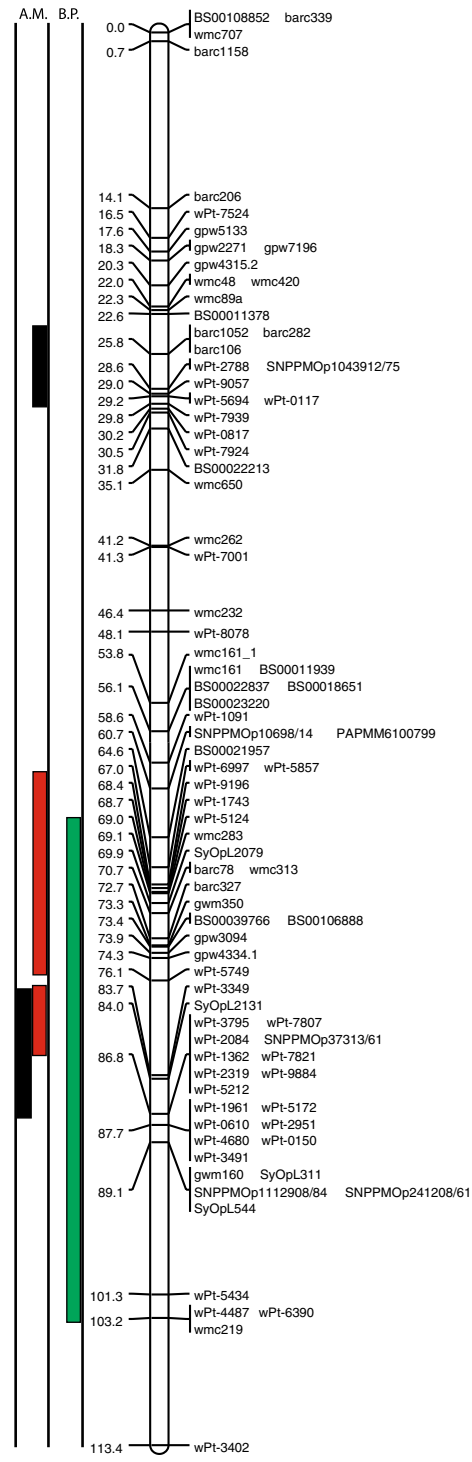

4B

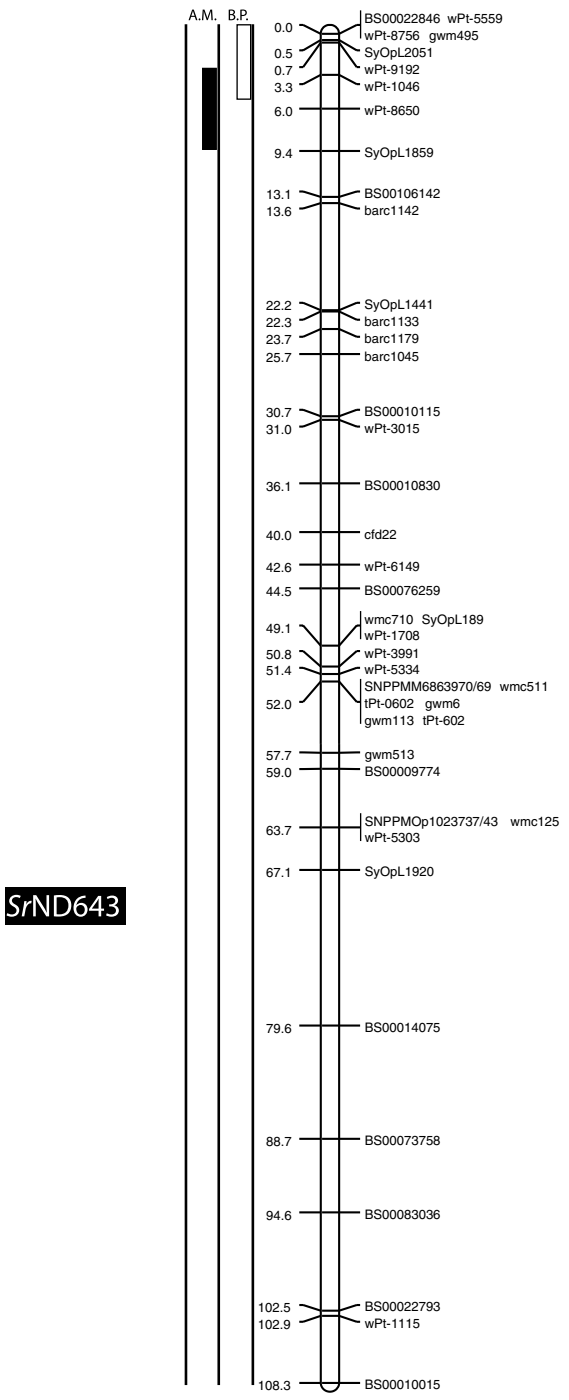

4D

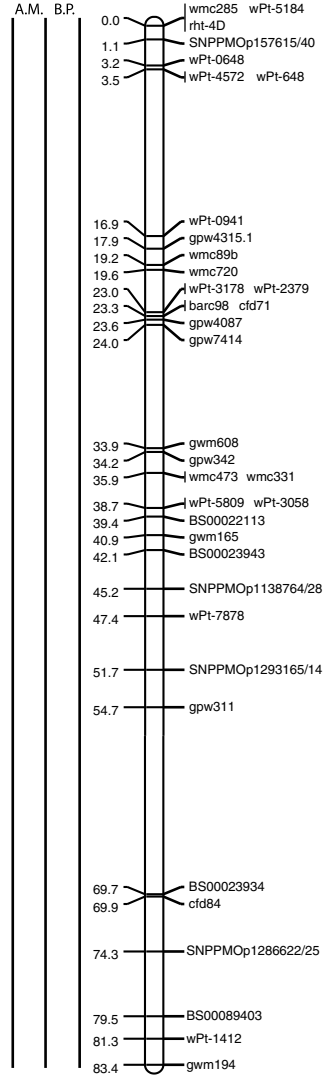

Fig. 2 continued

major Ug99 resistance genes are known to be located in this region. The $6 \mathrm{DS}$ chromosome arm had one resistance gene identified in a $\mathrm{BC}_{2}$ population (SrTA1662; $\mathrm{BC}_{2}$-TA10187/ KS05HW14: Olson et al. 2013) and a QTL identified in biparental crosses (AC Cadillac/Carberry: Lopez-Vera et al. 2014). Neither of the 6DS loci are shown in Fig. 2 because of difficulty in cross referencing the chromosome location. Four Ug99 resistance $\mathrm{Sr}$ genes have been identified on chromosome 6D. Three of them are located on the short arm, $\mathrm{Sr} 42$, SrTA10187 and SrCad (Hiebert et al. 2011; Ghazvini et al. 2012; Lopez-Vera et al. 2014) and one on the long arm, Sr29 (Dyck and Kerber 1977).

Group 7 had 30 QTL across the three homoeologous chromosomes. Three were mapped on 7AS, three on 7AL, and three have unknown locations. Seven were mapped in bi-parental populations (HD2009/WL711: Kaur et al. 2009; PBW343/Kingbird: Bhavani et al. 2011; PBW343/Diniza, PBW343/Kenya Swara, PBW343/Kenya Nyangumi: CIMMYT, unpublished; Kristal/Sebatel: Haile et al. 2012) and two were mapped by association mapping (AM durum panel: Letta et al. 2013). Five of these QTL are shown in Fig. 2. Gene Sr15 (not shown in Fig. 2) and Ug99 effective gene $\operatorname{Sr} 22$ (The 1973) are located on 7AL. On 7B there were ten QTL, five of which were mapped using bi-parental crosses (PBW343/Huirivis\#1: Bhavani et al. 2011; PBW343/Kenya Nyangumi, PBW343/Kenya Kudu: CIMMYT, unpublished; Avocet/Pavon76: Njau et al. 2013; Kristal/Sebatel: Haile et al. 2012) and five using 
5A

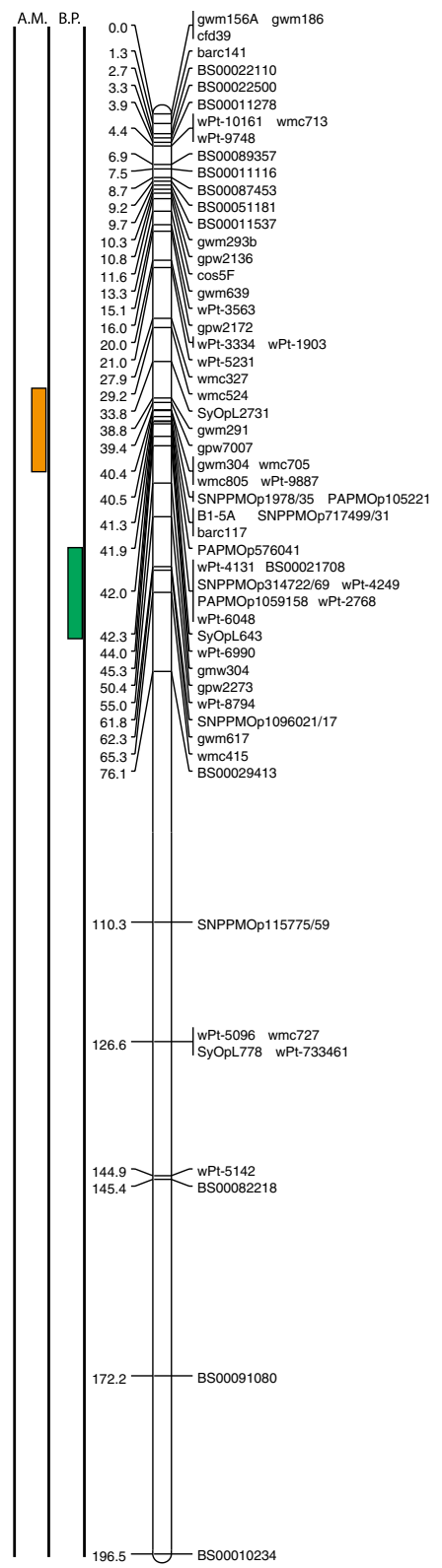

5B

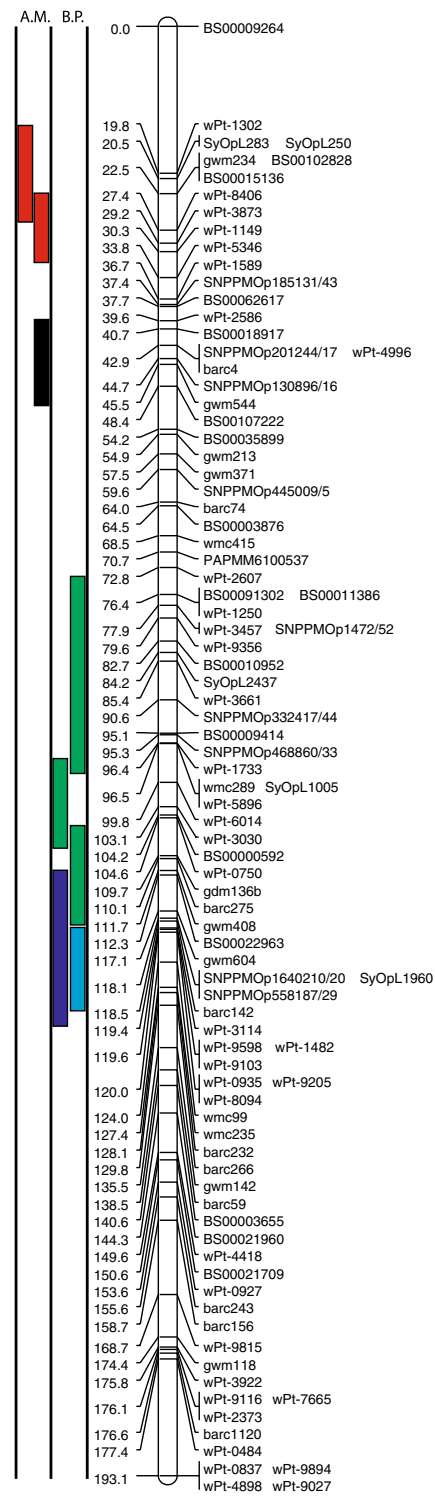

5D

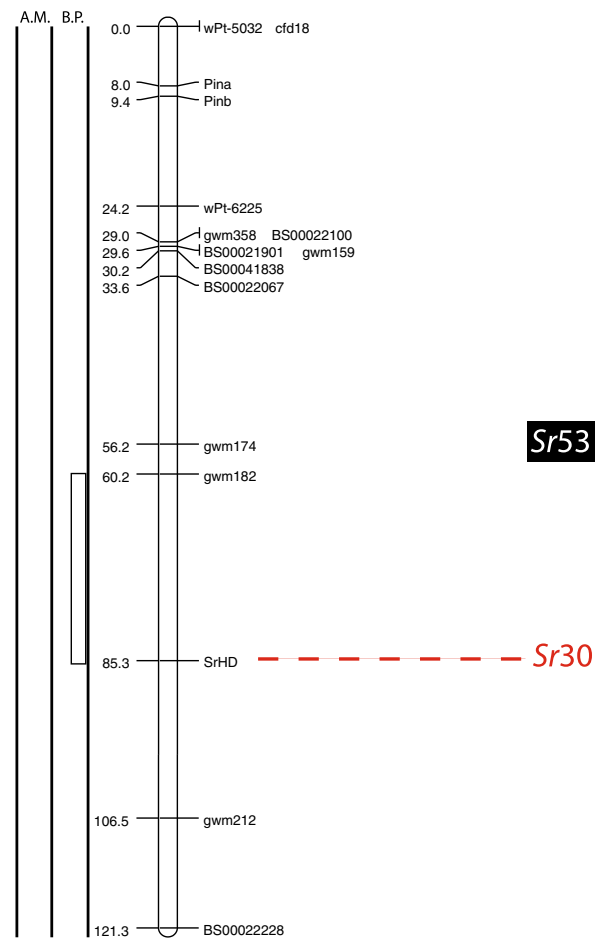

Fig. 2 continued

association analysis (ESWYT: Crossa et al. 2007; LDSRRSN (spring) and LD-SRRSN (winter): Yu et al. 2011). Seven of these QTL are represented in Fig. 2. Eight of these QTL are mapped near Sr17 (position not represented in Fig. 2) (Bansal et al. 2008). The 7D chromosome had 11 QTL, 6 mapped in bi-parental crosses (Thatcher/McNeal: Rouse et al. 2014; PBW343/Kiritaki, PBW343/Kingbird: Bhavani et al. 2011; Arina/Forno: Bansal et al. 2008; PBW343/Kenya Swara: CIMMYT, unpublished; BC2TA10171/KS05HW14: Olson et al. 2013), whereas five were mapped in association panels (ESWYT: Crossa et al. 2007; LD-SRRSN (spring) and LDSRRSN (winter):
Yu et al. 2011). Seven of these QTL are shown in Fig. 2. Pleiotropic rust and powdery mildew resistance gene Sr57 (Lr34/Yr18/Pm38), Sr44 as well as SrTA10171 are located on 7DS (Kolmer et al. 2011; Bernd Friebe, personal communication) and $S r 25$ as well as $S r 43$ (Xu et al. personal communication) are located on 7DL.

\section{Discussion}

Four maps including the Wheat Interpolated DArT Maps v4, the wheat consensus SSR map, the wheat KASPar 
6A

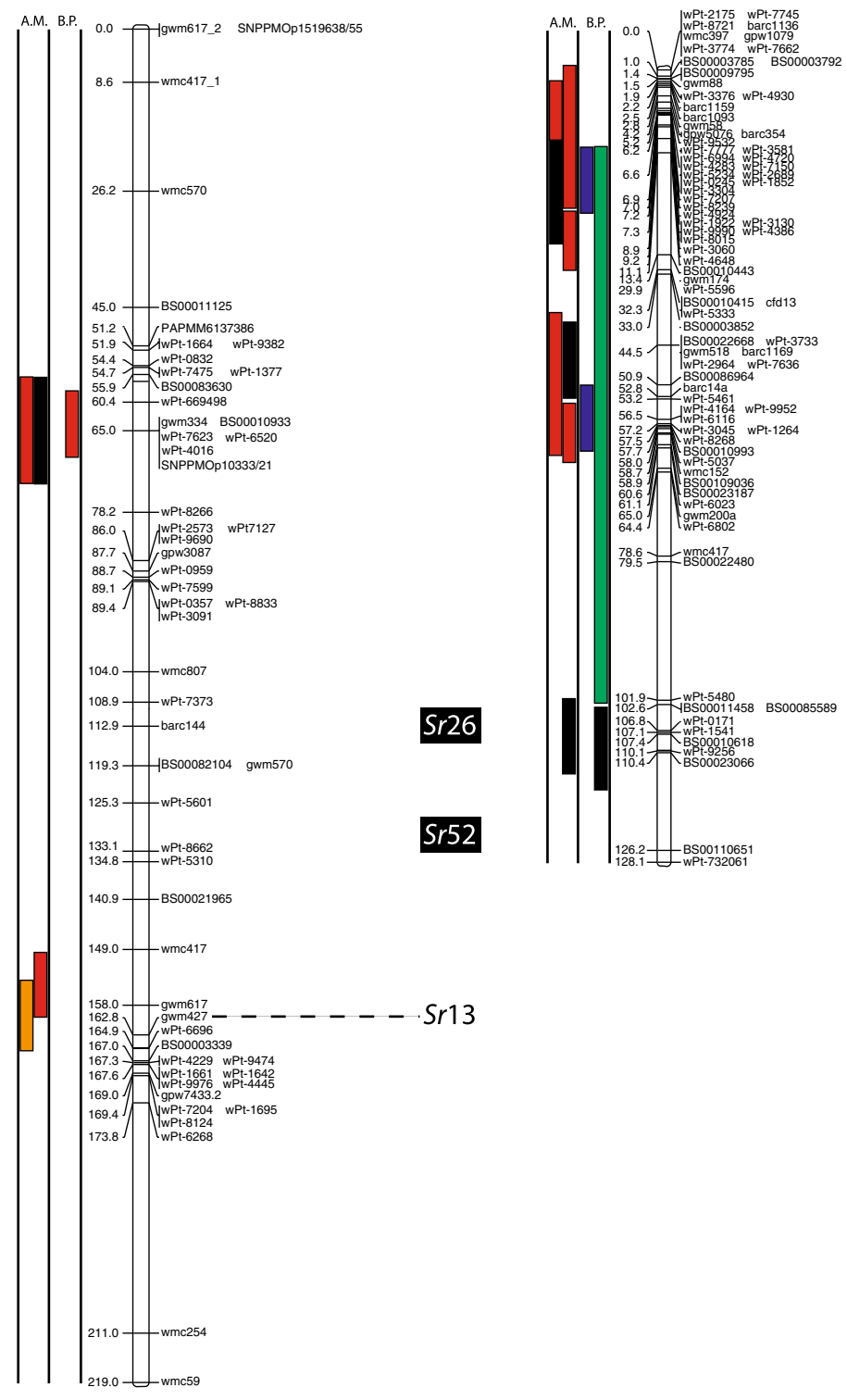

6D

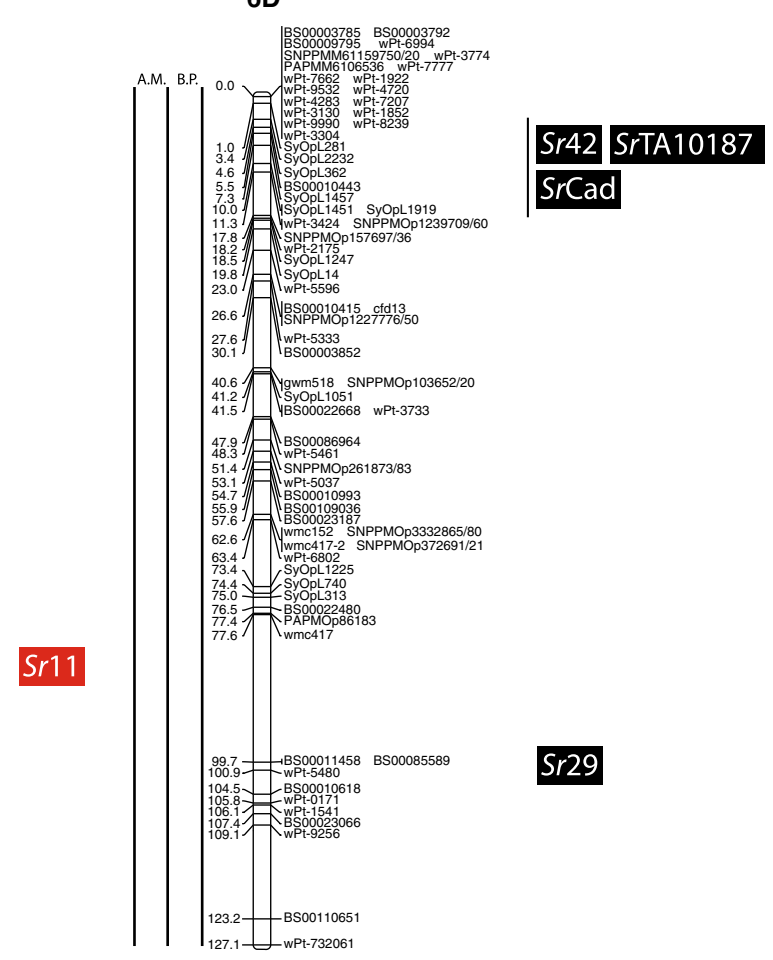

Fig. 2 continued

SNP map, and the Thatcher/McNeal DArT/SSR markers map were used to build the consensus map for locating the stem rust resistance loci (Fig. 2). The consensus map consisted of 1,433 markers and an average marker interval of $11.5 \mathrm{cM}$. We focused on integrating markers in the regions spanning stem rust resistance QTL that can further facilitate fine mapping and cross referencing the locations with other maps. Therefore, the marker density in the QTL regions is higher than the average. For example, marker density is almost three times higher in the QTL region of rust resistance genes on $1 \mathrm{~B}$ (Fig. 2, Chromosome $1 \mathrm{~B})$. The same is true for $2 \mathrm{BL}, 3 \mathrm{BS}, 4 \mathrm{AL}, 6 \mathrm{BS}$ and $7 \mathrm{DL}$. However, the complexity and context dependency of QTL identified in different genetic backgrounds and environments can limit the accuracy of the locations. The accurate genome location of QTL and major genes across genetic backgrounds and environments is a prerequisite for the use of the QTL in MAS. Meta-analysis of QTL identified in different studies can locate QTL more precisely, thus facilitating the identification of closely linked markers for MAS. Because many of the populations from which APR was assessed lacked Ug99-effective qualitative resistance genes, the coincidence of APR with seedling resistance was not likely to be a result of the qualitative resistance genes conferring APR. For example, on 2BS, seven QTL were identified that overlapped with two Ug99-effective stem 


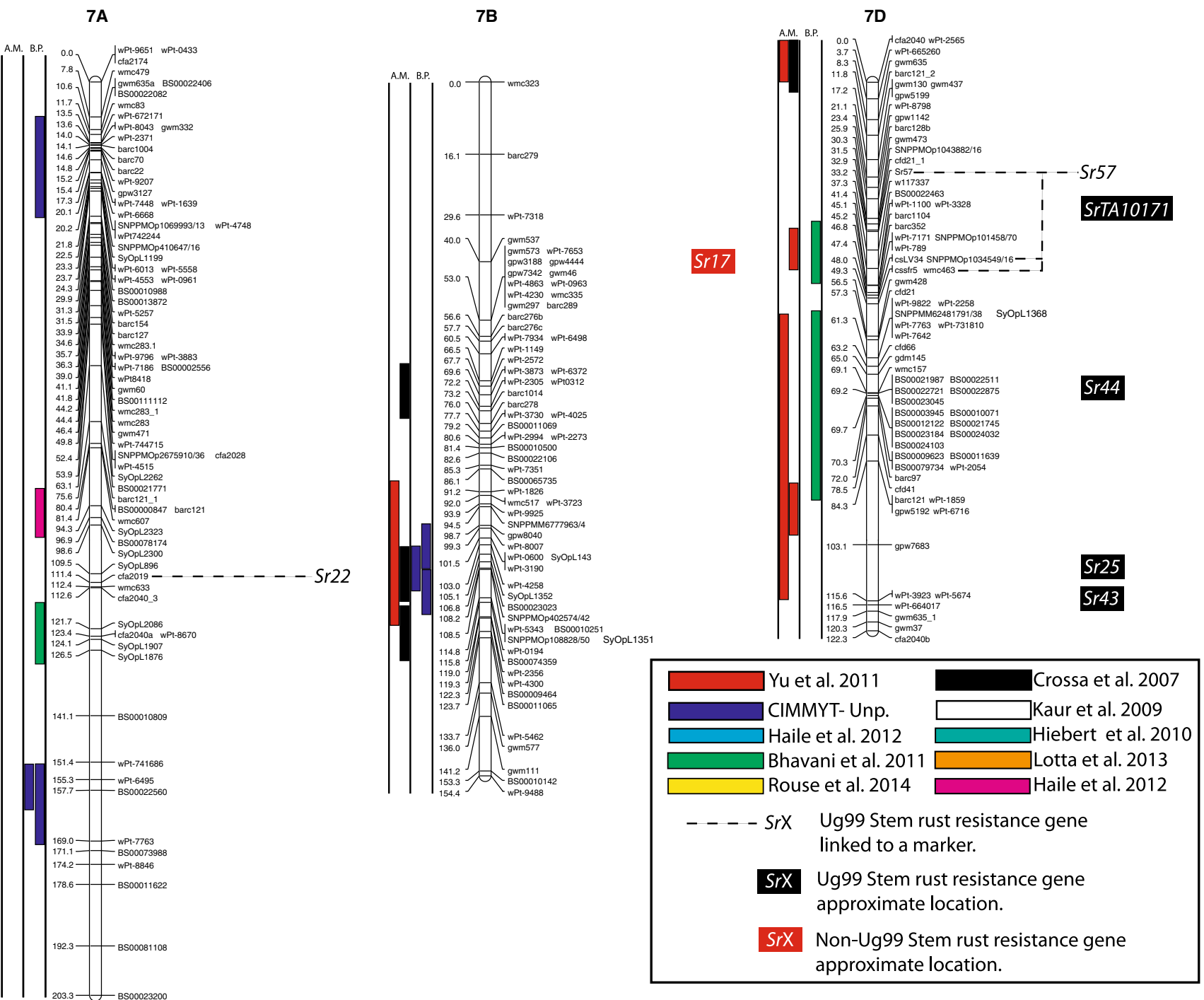

Fig. 2 continued

rust resistance genes, $\operatorname{Sr} 39$ and $\operatorname{Sr} 36$ (Fig. 2b). Since $\operatorname{Sr} 39$ was not present in the wheat cultivars used to map the QTL and $\operatorname{Sr} 36$ was only present in the germplasm analyzed by Yu et al. (2012) where no association was found between Sr36 and APR, the QTL on 2BS could be conferred by alleles of these qualitative genes, residual effects of other $\mathrm{Sr}$ genes on 2BS, or new genes. Similarly, the stem rust resistance gene $\mathrm{Sr} 40$ on $2 \mathrm{BS}$ is strongly associated with marker Xgwm388 and coincided with one QTL, however $\mathrm{Sr} 40$ was not present in the corresponding germplasm (Yu et al. 2011). Allelism testing utilizing both adult plant and seedling testing to identify both qualitative and quantitative resistance loci will be necessary to sort out the allelic relationships among many of the QTL and $S r$ genes reported on wheat chromosomes.

In spite of the complexity of the meta-QTL analysis, using the available information on the $S r$ genes in the parents of biparental populations and accessions used for association mapping combined with the QTL location based on anchored markers, we were able to identify (a) QTL underlying some previously described Ug99 resistant $\mathrm{Sr}$ genes or residual effects of non Ug99 resistant genes and (b) putative locations of new $\mathrm{Sr}$ genes.

Colocation of Sr genes and QTL

Even though $S r 31$ carried by the rye introgression 1BL.1RS is not effective to Ug99, the three QTL found on chromosome 1BS, homoeologous to $1 \mathrm{RS}$, are possibly due to a residual effect of $\mathrm{Sr} 31$ or another gene on the rye translocation because wheat cultivar PBW343 possesses Sr31. Additional studies are needed to validate whether the 1BS QTL are effects of the 1BL.1RS translocation or if there are one or more new APR genes on 1BS. Adult plant resistance 
gene $\operatorname{Sr} 58$ (Lr46/Yr29/Pm39) mapped distally on 1BL (McIntosh et al. 2012) and is independent of the seven QTL on chromosome 1BS. The response of Sr14 to Ug99 (Jin et al. 2007) was inconclusive, but because of its tetraploid origin and linkage to centromeric markers, the QTL on 1BS highlighted by Letta et al. (2013) is likely conferred by Sr14. Chromosome arm 2B, with 15 QTL, has the second highest number of QTL per chromosome arm, but also the highest number of known qualitative $\mathrm{Ug} 99 \mathrm{Sr}$ genes $(6$ numerically designated: $\operatorname{Sr} 39, \operatorname{Sr} 32, \operatorname{Sr} 36, \operatorname{Sr} 40, \operatorname{Sr} 47, \operatorname{Sr} 28$ and $\mathrm{SrWeb}$ ). Sorting out the allelic relationships among these QTL and at least 11 qualitative $S r$ genes (seven Ug99 resistant and four non $\mathrm{Ug} 99$ resistant $S r$ genes) on chromosome $2 \mathrm{~B}$ will be necessary to determine whether any new $S r$ genes have been detected or if they are the results of residual effects. The three QTL found in the AM durum panel (Letta et al. 2013) on chromosome 6AL overlap with $\mathrm{Sr} 13$, and even though $\mathrm{Sr} 13$ is not common in bread wheat, its presence in durum wheat suggests that the large region highlighted is most likely Srl3. Similarly, further studies are required to determine the allelic relationships among SrTA1662, SrCad, and Sr42 on 6DS (Hiebert et al. 2011; Ghazvini et al. 2012; Lopez-Vera et al. 2014). Chromosome 7B has nine QTL, eight of these QTL mapped near Srl7 (position not represented on Fig. 2) (Bansal et al. 2008). Though $\operatorname{Sr} 17$ is not effective to $\mathrm{Ug} 99$ in a qualitative manner (Jin et al. 2007) it is possible that $\operatorname{Sr} 17$ confers a residual APR effect. On chromosome 7D, early studies indicated that $\operatorname{Sr} 57$ (Lr34/Yrl8/Pm38), Sr58 ( $2 r 46 / Y r 29 /$ Pm39) enhanced stem rust resistance in cultivar 'Thatcher' (Dyck and Kerber 1977; Kerber and Aung 1999), and later reports suggested that $\operatorname{Sr} 57$ provided APR to stem rust in diverse backgrounds (McIntosh et al. 2012). Our previous studies consistently showed that the STS marker csLV34 was significantly associated with Ug99 resistance in winter and spring CIMMYT wheat panels with major effects or through gene-gene interactions (Yu et al. 2011, 2012). Overlap of two QTL located distally on 7DL (Yu et al. 2011) are likely conferred by $S r 25$ (Ayala-Navarrete et al. 2007) because $\mathrm{Sr} 43$ and $\mathrm{Sr} 44$ are not currently used in wheat breeding.

\section{Putative locations of new $\mathrm{Sr}$ genes}

With six QTL found on 1A, that chromosome could be a potential new source of new APR. Because $\operatorname{Sr} 1 R S^{\text {Amigo }}$ was introgressed from rye and confers qualitative resistance, it is most likely different from the six QTL on 1A. The same is true for the two QTL found on chromosome 1D. Even though they overlap with four described Ug99 resistant $\mathrm{Sr}$ genes (SrTA1662, Sr33, Sr45, Sr50: Rouse et al. 2011; Sambasivam et al. 2008; Anugrahwati et al. 2008), the Aegilops tauschii or rye origin of these genes make it unlikely that these QTL are related. The two QTL found on chromosome 2A are likely to represent new Ug99 $\mathrm{Sr}$ resistance loci because the only known gene in the region, Sr21 (The 1973), is derived from T. monococcum, and because the parents of the population with the $2 \mathrm{~A}$ QTL (PBW343/Pavon76: CIMMYT unpublished) are not known to possess T. monococcum in their pedigrees. Also, $\mathrm{Sr} 21$ was not in the pedigrees of the AM durum panel (Letta et al. 2013). Chromosome group 3 has the second highest number of QTL, and chromosome 3B, with 23 QTL has the highest number of QTL by chromosome arm (Fig. 1). Chromosome arm 3BS has only one $\mathrm{Ug} 99 \mathrm{Sr}$ resistant gene, the slow rusting gene $S r 2$ and 19 of the QTL found on that arm are likely $S r 2$. In the Thatcher/McNeal population, a QTL was coincident with Sr12 on 3BL, a Ug99-ineffective resistance gene. It is possible that such defeated resistance genes could confer resistance when combined with genes such as $\operatorname{Sr} 57$ (Lr34/Yr18/Pm38) that have been demonstrated to confer epistatic resistance to stem rust (Kolmer et al. 2011; Rouse et al. 2014; Yu et al. 2012). Because Sr12 is present in the cultivar Thatcher and historically was used as an important source of resistance, Sr 12 could be widespread in wheat germplasm. Since no resistance genes have been characterized on 3BL, the QTL in this region are conferred by one or more new resistance genes. Ug99 resistance gene $\mathrm{Sr} 51$ has been introgressed into translocations on each of the group 3 homoeologous chromosomes (Liu et al. 2011b). Since this gene is derived from Aegilops searsii and is not currently used in agriculture, none of the group 3 QTL are conferred by this gene. Chromosome 3A has three QTL, and the $S r 35$ cloned gene seems to overlap with the QTL in a CIMMYT population (CIMMYT unpublished) and in the durum panel (Letta et al. 2013) on chromosome 3AL, these QTL are not Sr35 because seedling resistance to race TTKSK is absent in the mapping population used by CIMMYT. In addition, the T. monococcum origin of $\mathrm{Sr} 35$ is absent from the pedigrees of the panel used by Letta et al. (2013). Resistance gene $\operatorname{Sr} 27$ is also on 3A, but this gene is different from these QTL because it is located on a rye introgression not present in the population used to identify these QTL. On Chromosome 4A, the stem rust resistance gene designated $\operatorname{SrND643}$ (CIMMYT unpublished) is a qualitative gene and the PBW343/Juchi population does not possess that resistance gene so the QTL from PBW343/Juchi is likely conferred by a new resistance gene or allele. The relationships among the QTL identified on 4AL, SrND643, and $\operatorname{Sr} 7$ (Singh et al. 2006; Sears 1954) are not known. The distal end of chromosome 4B appears to be the source of a new $S r$ gene, although the variance explained for the QTL is low (9\%) and may represent a minor effect APR gene. Chromosome 5A does not carry any previously characterized $\mathrm{Sr}$ genes, so the three QTL identified on that chromosome arm likely represent 
new resistance loci. Although the phenotypic variation for the two QTL identified by Letta et al. (2013) on durum wheat is small $\left(R^{2}=4.1\right.$ and $\left.4.4 \%\right)$, further studies of that region could support the existence of new Ug99 resistant loci. The APR gene Sr56 (McIntosh et al. 2012) on chromosome 5BL was previously designated QSr.Sun-5BL (Bansal et al. 2008) (not represented in Fig. 2). Among the 12 other QTL found on 5B, at least four are located on the short arm (Bansal et al. 2008; CIMMYT unpublished; Kaur et al. 2009; Yu et al. 2011) and likely represent new loci of importance. Although Kaur et al. (2009) did not test for APR to Ug99, Yu et al. (2011) also mapped distal 5BS QTL providing strong evidence for minor APR genes located in this region. Resistance gene $S r 26$ on 6AL is present in conventional common wheat germplasm from Australia, but was not present in CIMMYT germplasm when these studies were conducted. Therefore $\operatorname{Sr} 26$ does not explain the QTL identified through association mapping (Crossa et al. 2007; Yu et al. 2011). A putative new resistance QTL on 6AS was mapped in the hexaploid biparental PBW343/ Kenya Swara population where no qualitative resistance genes are located (CIMMYT, unpublished). The QTL found on 6AL in the tetraploid population Kristal/Sebatel is likely a new source of resistance since Sr13-linked markers are in the distal region of 6AL. Chromosome 6B seems to be a rich source of new $\mathrm{Sr}$ genes with nine QTL detected. The relationship between the QTL on 6BL and Srl1 is not known but $\mathrm{Srll}$ is ineffective against $\mathrm{Ug} 99$ and is not represented on Fig. 2. Chromosome arm 6BS appears to be a new source of $\mathrm{Sr}$ genes (Crossa et al. 2007; Yu et al. 2011; CIMMYT unpublished). The phenotypic variation explained by these QTL ranged from 5 to $14 \%$ and most likely correspond to minor APR genes. Singh et al. (2011) detected a distal QTL that explained $56 \%$ of the variance for stem rust on chromosome 6BS (XwPt4283/XwPt7207) in the bi-parental cross between PBW343/Kenya Nyangumi. Validation of that QTL could be accomplished using the putative allele carrier, Kenya Nyangumi, in another bi-parental cross. The QTL on 7AS, either from durum or bread wheat, once validated, would represent new stem rust resistance genes as $\mathrm{Sr} 22$ is located on 7AL. Since $\mathrm{Sr} 22$ was not present in the parents of the hexaploid mapping populations, these QTL are not conferred by $S r 22$. The more distal QTL found in the Kristal/Sebatel bi-parental tetraploid population (QSr.1PK-7A.2) is likely to be conferred by $S r 22$ (Haile et al. 2012). Since $S r$ genes have not been previously identified on 7BS, the QTL identified in this region are likely new.

Overall, the growing number of characterized $\mathrm{Sr}$ genes and QTL demonstrates that there is still potential for discovering new APR genes with varying levels of effect. This consensus map will facilitate the identification of new resistance genes and QTL and aid in the development of improved markers to increase breeding efficiency and the pool of alleles that are important for the control of $\mathrm{Ug} 99$.

Conflict of interest None of the people involved in this publication have a conflict of interest with the content presented.

Open Access This article is distributed under the terms of the Creative Commons Attribution License which permits any use, distribution, and reproduction in any medium, provided the original author(s) and the source are credited.

\section{References}

Acosta AG (1963) The transfer of stem rust resistance from rye to wheat. Dis Abstr 22:34-35

Anugrahwati DR, Shepherd KW, Verlin DC, Zhang P, Mirzaghaderi G, Walker E, Francki MG, Dundas IS (2008) Isolation of wheatrye 1 RS recombinants that break the linkage between the stem rust resistance gene $\operatorname{SrR}$ and secalin. Genome 51:341-349

Ayala-Navarrete L, Bariana HS, Singh RP, Gibson JM, Mechanicos AA, Larkin PJ (2007) Trigenomic chromosomes by recombination of Thinopyrum intermedium and Th. ponticum translocations in wheat. Theor Appl Genet 116:63-75

Bansal UK, Bossolini E, Miah H, Keller B, Park RF, Bariana HS (2008) Genetic mapping of seedling and adult plant stem rust resistance in two European winter wheat cultivars. Euphytica 164:821-828

Bhavani S, Singh RP, Argillier O, Huerta-Espino J, Singh S, Njau P, Brun S, Lacam S and Desmouceaux N (2011) Mapping durable adult plant stem rust resistance to the race Ug99 group in six CIMMYT wheats. 2011 BGRI Technical Workshop, pp 43-53

Crossa J, Burgueno J, Dreisigacker S, Vargas M, Herrera-Foessel SA, Lillemo $M$ et al (2007) Association analysis of historical bread wheat germplasm using additive genetic covariance of relatives and population structure. Genetics 177:1889-1913

Dyck PL, Kerber ER (1977) Chromosome location of gene Sr29 for reaction to stem rust. Can J Genet Cytol 19:371-373

Endelman J, Plomion C (2011) LPmerge: An R package for merging genetic maps by linear programming. BMC Bioinformatics 11:1623-1624

Faris JD, Xu SS, Cai X, Friesen TL, Jin Y (2008) Molecular and cytogenetic characterization of a durum wheat-Aegilops speltoides chromosome translocation conferring resistance to stem rust. Chromosom Res 16:1097-1105

Ghazvini H, Hiebert CW, Zegeye T, Liu S, Dilawari M, Tsilo T, Anderson JA, Rouse MN, Jin Y, Fetch T (2012) Inheritance of resistance to Ug99 stem rust in wheat cultivar Norin 40 and genetic mapping of $S r 42$. Theor Appl Genet 125:817-824

Gustafson GD, Shaner G (1982) Influence of plant age on the expression of slow-mildewing resistance in wheat. Phytopathology 72:746-749

Haile JK, Nachit MM, Hammer K, Badebo A, Roder MS (2012) QTL mapping of resistance to race Ug99 of Puccinia graminis f. sp. tritici in durum wheat (Triticum durum Desf.). Mol Breed 30:1479-1493

Hart GE, Gale MD, McIntosh RA (1993) Linkage maps of Triticum aestivum (hexaploid wheat, $2 \mathrm{n}=42$, genomes $\mathrm{A}, \mathrm{B}$, and $\mathrm{D}$ ) and T. tauschii $(2 \mathrm{n}=14$, genome D). GrainGenes Reference Report 6204-6219

Heerman RM, Stoa TE (1956) New durum wheats resistant to 15B. N Dak Agr Expt Sta Bimonth Bul 18:75-80 (illus)

Hiebert CW, Fetch TG, Zegeye T (2010) Genetics and mapping of stem rust resistance to $\mathrm{Ug} 99$ in the wheat cultivar Webster. Theor Appl Genet 121:65-69 
Hiebert CW, Fetch TG, Zegeye T, Thomas JB, Somers DJ, Humphreys DG, McCallum BD, Cloutier S, Singh D, Knott DR (2011) Genetics and mapping of seedling resistance to Ug99 stem rust in Canadian wheat cultivars 'Peace' and 'AC Cadillac'. Theor Appl Genet 122:143-149

Hudson CJ, Freeman JS, Kullan ARK, Petroli CD, Sansaloni CP, Kilian A, Detering F, Grattapaglia D, Potts BM, Myburg AA, Vaillancourt RE (2012) A reference linkage map for Eucalyptus. BMC Genomics 13:240

Jin Y, Singh RP (2006) Resistance in U.S. wheat to recent Eastern African isolates of Puccinia graminis f. sp. tritici with virulence to resistance gene Sr31. Plant Dis 90:476-480

Jin Y, Singh RP, Ward RW, Wanyera R, Kinyua M, Njau P, Pretorius ZA (2007) Characterization of seedling infection types and adult plant infection responses of monogenic Sr gene lines to race TTKSK of Puccinia graminis f. sp. tritici. Plant Dis 91:1096-1099

Jin Y, Szabo LJ, Pretorius ZA, Singh RP, Ward R, Fetch T Jr (2008) Detection of virulence to resistance gene $\operatorname{Sr} 24$ within race TTKS of Puccinia graminis f. sp. tritici. Plant Dis 92:923-926

Jin Y, Szabo LJ, Rouse MN, Fetch T Jr, Pretorius ZA, Wanyera R, Njau P (2009) Detection of virulence to resistance gene Sr36 within the TTKS race lineage of Puccinia graminis f. sp. tritici. Plant Dis 93:367-370

Kaur J, Bansal U, Khanna R, Saini RG, Bariana H (2009) Molecular mapping of stem rust resistance in HD2009/WL711 recombinant inbred line population. Int J Plant Breed 3:28-33

Kerber ER, Aung T (1999) Leaf rust resistance gene associated with nonsuppression of stem rust resistance in wheat cultivar Canthatch. Phytopathology 89:518-521

Klindworth DL, Niu ZX, Chao SM, Friesen TL, Jin Y, Faris JD, Cai XW, Xu SS (2012) Introgression and characterization of a goatgrass gene for a high level of resistance to $\mathrm{Ug} 99$ stem rust in tetraploid wheat. G3 2:665-673

Kolmer JA, Garvin DF, Jin Y (2011) Expression of a Thatcher wheat adult plant stem rust resistance QTL on chromosome arm $2 \mathrm{BL}$ is enhanced by $L r 34$. Crop Sci 51:526-533

Letta T, Maccaferri M, Badebo A, Ammar K, Ricci A, Crossa J, Tuberosa R (2013) Searching for novel sources of field resistance to Ug99 and Ethiopian stem rust races in durum wheat via association mapping. Theor Appl Genet 126:1237-1256

Liu W, Jin Y, Rouse M, Friebe B, Gill B, Pumphrey MO (2011a) Development and characterization of wheat-Ae. searsii Robertsonian translocations and a recombinant chromosome conferring resistance to stem rust. Theor Appl Genet 122:1537-1545

Liu W, Rouse M, Friebe B, Jin Y, Gill B, Pumphrey MO (2011b) Discovery and molecular mapping of a new gene conferring resistance to stem rust, Sr53, derived from Aegilops geniculata and characterization of spontaneous translocation stocks with reduced alien chromatin. Chromosom Res 19(5):669-682

Lopez-Vera EE, Nelson S, Singh RP, Basnet BR, Haley SD, Bhavani S, Huerta-Espino J, Xoconostle-Cazares BG, Ruiz-Medrano R, Rouse MN, Sukhwinder-Singh (2014) Resistance to stem rust Ug99 in six bread wheat cultivars maps to chromosome 6DS. Theor Appl Genet 127:231-239

Mago R, Verlin D, Zhang P, Bansal U, Bariana H, Jin Y, Ellis J, Hoxha S, Dundas I (2013) Development of wheat-Aegilops speltoides recombinants and simple PCR-based markers for Sr32 and a new stem rust resistance gene on the $2 \mathrm{~S} \# 1$ chromosome. Theor Appl Genet 126:2943-2955

McIntosh RA (1972) Cytogenetical studies in wheat VI. Chromosome location and linkage studies involving $\mathrm{Sr} 13$ and $\mathrm{Sr} 8$ for reaction to Puccinia graminis f. sp. tritici. Aust J Biol Sci 25:765-773

McIntosh RA, Wellings CR, Park RF (1995) Wheat rusts, an atlas of resistance genes. CSIRO Publications, East Melbourne, pp 93-99
McIntosh RA, Dubcovsky J, Rogers WJ, Morris CF, Appels R, Xia XC (2011) Catalogue of gene symbols for wheat: 2011 supplement. Annu Wheat Newsl 57:303-321

McIntosh RA, Dubcovsky J, Rogers WJ, Morris CF, Appels R, Xia XC (2012) Catalogue of gene symbols for wheat: 2012 supplement. Ann Wheat Newsl 58:259-279

Niu Z, Klindworth DL, Friesen TL, Chao S, Jin Y, Cai X, Xu SS (2011) Targeted introgression of a wheat stem rust resistance gene by DNA marker-assisted chromosome engineering. Genetics 187(4):1011-1021

Njau PN, Bhavani S, Huerta-Espino J, Keller B, Singh RP (2013) Identification of QTL associated with durable adult plant résistance to stem rust race Ug99 in wheat cultivar 'Pavon 76'. Euphytica 190:33-44

Olson EL, Rouse MN, Pumphrey MO, Bowden RL, Gill BS, Poland JA (2013) Introgression of stem rust resistance genes SrTA10187 and SrTA10171 from Aegilops tauschii to wheat. Theor Appl Genet. doi:10.1007/s00122-013-2148-z

Periyannan S, Moore J, Ayliffe M, Bansal U, Wang X, Deal K, Luo M, Kong X, Bariana H, Mago R, McIntosh R, Dodds P, Dvorak J, Lagudah E (2013) The gene Sr33, an ortholog of Barley Mla genes, encodes resistance to wheat stem rust race Ug99. Science 341(6147):786-788

Pretorius ZA, Singh RP, Wagoire WW, Payne TS (2000) Detection of virulence to wheat stem rust resistance gene Sr31 in Puccinia graminis f. sp. tritici in Uganda. Plant Dis 84:203

Pretorius ZA, Szabo LJ, Boshoff WHP, Herselman L, Visser B (2012) First report of a new TTKSF race of wheat stem rust (Puccinia graminis f. sp. tritici) in South Africa and Zimbabwe. Plant Dis 96:590

Qi LL, Pumphrey MO, Friebe B, Zhang P, Qian C, Bowden RL, Rouse MN, Jin Y, Gill BS (2011) A novel Robertsonian translocation event leads to transfer of a stem rust resistance gene (Sr52) effective against race Ug99 from Dasypyrum villosum into bread wheat. Theor Appl Genet 123:159-167

Ronin Y, Mester D, Minkov D, Belotserkovski R, Jackson BN, Schnable PS, Aluru S, Korol A (2012) Two-phase analysis in consensus genetic mapping. G3 (Bethesda) 2:537-549

Rouse MN, Jin Y (2011) Stem rust resistance in A-genome diploid relatives of wheat. Plant Dis 95:941-944

Rouse M, Olson E, Gill B, Pumphrey M, Jin Y (2011) Stem rust resistance in Aegilops tauschii germplasm. Crop Sci 51:2074-2078

Rouse MN, Nava IC, Chao S, Anderson JA, Jin Y (2012) Identification of markers linked to the race Ug99 effective stem rust resistance gene $\operatorname{Sr} 28$ in wheat (Triticum aestivum L.). Theor Appl Genet 125:877-885

Rouse MN, Talbert LE, Singh D, Sherman JD (2014) Complementary epistasis involving $\mathrm{Sr} 12$ explains adult resistance to stem rust in Thatcher wheat (Triticum aestivum L.) Theor Appl Genet. doi:10.1007/s00122-014-2319-6

Saintenac C, Zhang W, Salcedo A, Rouse MN, Trick HN, Akhunov E, Dubcovsky J (2013) Identification of wheat gene Sr35 that confers resistance to $\mathrm{Ug} 99$ stem rust race group. Science 341(6147):783-786

Sambasivam PK, Bansal UK, Hayden MJ, Dvorak J, Lagudah ES, Bariana HS (2008) Identification of markers linked with stem rust resistance genes $\mathrm{Sr} 33$ and Sr45. In: Appels R, Eastwood R, Lagudah E, Langridge P, Mackay M, McIntyre L, Sharp P (eds) Proceedings of 11th international wheat genetics symposium. Sydney University Press, Sydney, pp 351-353

Schlegel R, Kynast R (1987) Confirmation of a 1A1R wheat-rye chromosome translocation in the wheat variety 'Amigo'. Plant Breed 98:57-60

Sears ER (1954) The aneuploids of common wheat. GrainGenes Reference Report 572 
Sharma RK, Singh PK, Vinod, Joshi AK, Bhardwaj SC, Bains NS, Sukwinder-Singh (2013) Protecting south Asia wheat production from stem rust (Ug99) epidemic. J Phytopathol 161:299-307

Sherman JD, Martin JM, Blake NK, Lanning SP, Talbert LE (2013) Genetic basis of agronomic differences between a modern and a historical spring wheat cultivar. Crop Sci 54:1-13

Singh RP, Hodson DP, Jin Y, Huerta-Espino J et al (2006) Current status, likely migration and strategies to mitigate the threat to wheat from race Ug99 (TTKS) of stem rust pathogen. CAB Rev Perspect Agric Vet Sci Nutr Nat Resour 1:1-13

Singh RP, Hodson DP, Huerta-Espino J, Jin Y, Bhavani S, Njau P, Herrera-Foessel S, Singh PK, Singh S, Govindan V (2011) The Emergence of $\mathrm{Ug} 99$ races of the stem rust fungus is a threat to world wheat production. Annu Rev Phytopathol 49:465-481. doi:10.1146/annurev-phyto-072910-095423

Singh A, Pandey MP, Singh AK, Knox RE, Ammar K, Clarke JM, Clarke FR, Singh RP, Pozniak CJ, DePauw RM, McCallum BD, Cuthbert RD, Randhawa HS, Fetch TG Jr (2013a) Identification and mapping of leaf, stem and stripe rust resistance quantitative trait loci and their interactions in durum wheat. Mol Breed 31:405-418

Singh A, Knox RE, DePauw RM, Singh AK, Cuthbert RD, Campbell HL, Singh D, Bhavani S, Fetch T, Clarke F (2013b) Identification and mapping in spring wheat of genetic factors controlling stem rust resistance and the study of their epistatic interactions across multiple environments. Theor Appl Genet 126:1951-1964

Singh S, Singh RP, Bhavani S, Huerta-Espino J, Lopez-Vera EE (2013c) QTL mapping of slow-rusting, adult plant resistance to race Ug99 of stem rust fungus in PBW343/Muu RIL population. Theor Appl Genet 126:1367-1375

Somers D, Isaac P, Edwards K (2004) A high-density microsatellite consensus map for bread wheat (Triticum aestivum L.). Theor Appl Genet 109:1105-1114

The TT (1973) Chromosome location of genes conditioning stem rust resistance transferred from diploid to hexaploid wheat. Nat New Biol 241:256

Van Ooijen JW (2006) JoinMap 4: software for the calculation of genetic linkage maps in experimental populations. In: Kyazma BV (ed). The Netherlands, Wageningen

Wenzl P, Li H, Carling J, Zhou M, Raman H, Paul E, Hearnden P, Maier C, Xia L, Caig V, Ovesná J, Cakir M, Poulsen D, Wang J, Raman R, Smith KP, Muehlbauer GJ, Chalmers KJ, Kleinhofs A, Huttner E, Kilian A (2006) A high-density consensus map of barley linking DArT markers to SSR, RFLP and STS loci and agricultural traits. BMC Genomics 7:206

Wu S, Pumphrey M, Bai G (2008) Molecular mapping of stem-rustresistance gene $\mathrm{Sr} 40$ in wheat. Crop Sci 49:1681-1686

Yu L-X, Lorenz A, Rutkoski J, Singh RP, Bhavani S, Huerta-Espino J, Sorrells ME (2011) Association mapping and gene-gene interaction for stem rust resistance in spring wheat germplasm. Theor Appl Genet 123:1257-1268

Yu L-X, Morgounov A, Wanyera R, Keser M, Singh SK, Sorrells M (2012) Identification of Ug99 resistance loci in winter wheat germplasm using genome-wide association analysis. Theor Appl Genet 125:749-758 